Review

\title{
Polymer functionalized nanocomposites for metals removal from water and wastewater: An overview
}

\author{
Giusy Lofrano a, b, Maurizio Carotenuto a , Giovanni Libralato ${ }^{c}{ }^{*}$, Rute F. Domingos ${ }^{\mathrm{d}}$, \\ Arjen Markus ${ }^{\mathrm{e}}$, Luciana Dini ${ }^{\mathrm{f}}$, Ravindra Kumar Gautam ${ }^{\mathrm{g}}$, Daniela Baldantoni ${ }^{\mathrm{a}}$, \\ Marco Rossi $^{\text {h }}$, Sanjay K. Sharma ${ }^{\text {i }}$, Mahesh Chandra Chattopadhyaya ${ }^{\mathrm{g}}$, Maurizio Giugni ${ }^{\mathrm{b}}$, \\ Sureyya Meric ${ }^{\mathrm{j}}$
}

a Department of Chemistry and Biology, University of Salerno, Via Giovanni Paolo II 132, 84084 Fisciano, Salerno, Italy

${ }^{\mathrm{b}}$ Department of Environmental and Civil Engineering, University of Naples "Federico II", Via Claudio 21, 80127 Naples, Italy

${ }^{\mathrm{c}}$ Department of Environmental Sciences, Informatics and Statistics, Cà Foscari University of Venice, Via Torino 155, 30172, Mestre-Venezia, Italy

${ }^{\mathrm{d}}$ Institut de Physique du Globe de Paris, Sorbonne Paris Cite, Universite; Paris Diderot, UMR CNRS 7154, 75238 Paris Cedex 05, France

e Deltares, PO Box 177, 2600 MH Delft, The Netherlands

${ }^{\mathrm{f}}$ Department of Biological and Environmental Science and Technology, University of Salento Prov.le Lecce-Monteroni, 73100 Lecce, Italy

${ }^{g}$ Environmental Chemistry Research Laboratory, Department of Chemistry, University of Allahabad, Allahabad 211 002, India

${ }^{\mathrm{h}}$ Dipartimento di Scienze di Base e Applicate per l'Ingegneria, Via Antonio Scarpa 14/16, 00161 Roma, Italy

i Green Chemistry \& Sustainability Research Group, Department of Chemistry, JECRC University, Jaipur 303905, India

${ }^{j}$ Corlu Engineering Faculty, Environmental Engineering Department, Namık Kemal University, Corlu 59860, Tekirdag, Turkey

\section{A R T I C L E I N F O}

\section{Article history:}

Received 16 September 2015

Received in revised form

4 January 2016

Accepted 15 January 2016

Available online 19 January 2016

\section{Keywords:}

Polymer functionalized nano-composites

Metalloid

Metal

Nanoparticles

Removal efficiency

Toxicity

\begin{abstract}
A B S T R A C T
Pollution by metal and metalloid ions is one of the most widespread environmental concerns. They are non-biodegradable, and, generally, present high water solubility facilitating their environmental mobilisation interacting with abiotic and biotic components such as adsorption onto natural colloids or even accumulation by living organisms, thus, threatening human health and ecosystems. Therefore, there is a high demand for effective removal treatments of heavy metals, making the application of adsorption materials such as polymer-functionalized nanocomposites (PFNCs), increasingly attractive. PFNCs retain the inherent remarkable surface properties of nanoparticles, while the polymeric support materials provide high stability and processability. These nanoparticle-matrix materials are of great interest for metals and metalloids removal thanks to the functional groups of the polymeric matrixes that provide specific bindings to target pollutants. This review discusses PFNCs synthesis, characterization and performance in adsorption processes as well as the potential environmental risks and perspectives.
\end{abstract}

(c) 2016 Elsevier Ltd. All rights reserved.

\section{Contents}

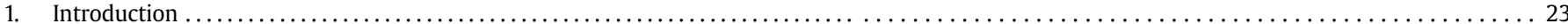

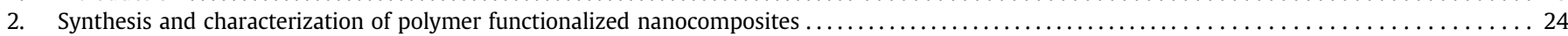

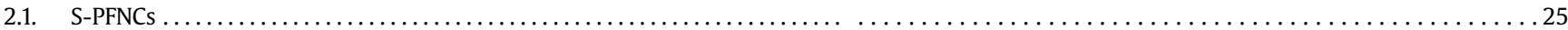

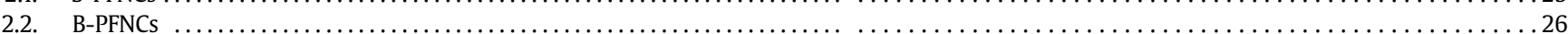

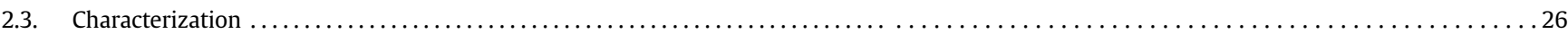

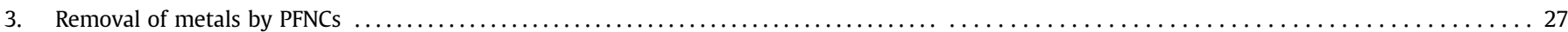

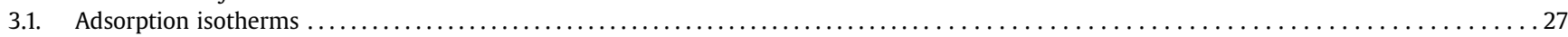

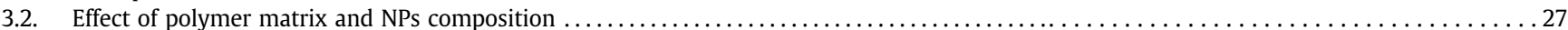

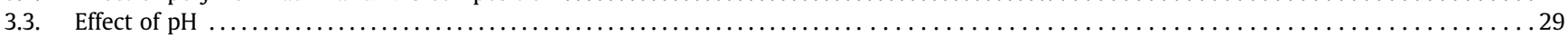

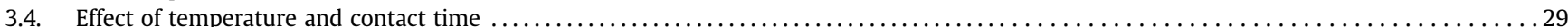

\footnotetext{
* Corresponding author. Via Torino 155, 30172 Venezia, Italy.

E-mail address: giovanni.libralato@unive.it (G. Libralato).
} 


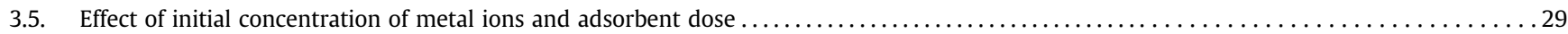

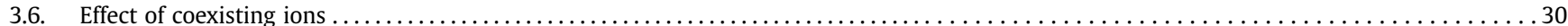

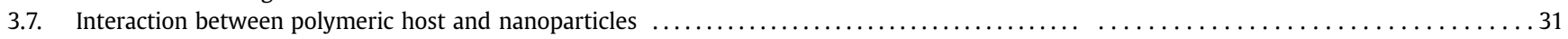

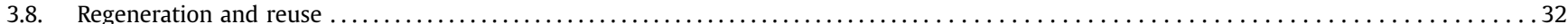

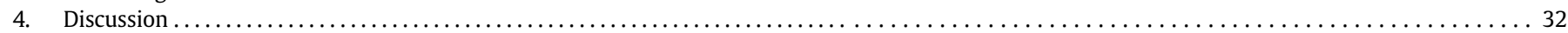

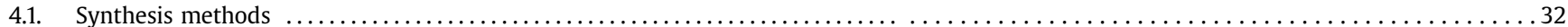

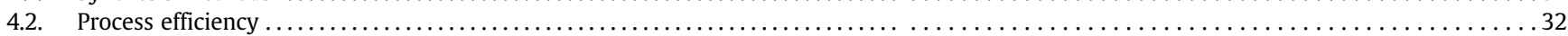

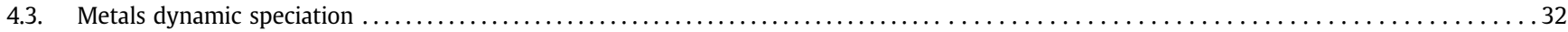

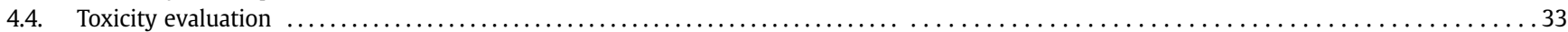

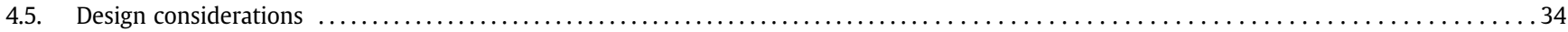

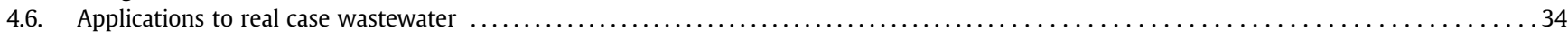

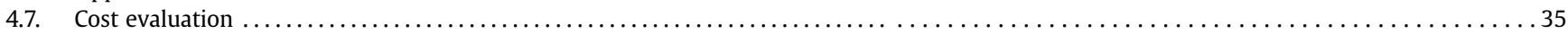

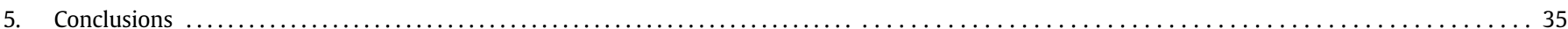

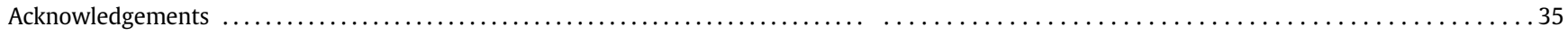

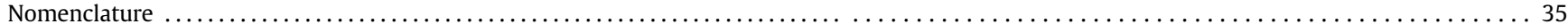

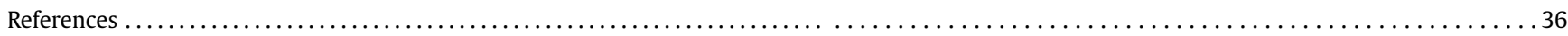

\section{Introduction}

As a consequence of the growing pressure on water supply, the use of unconventional water sources such as treated wastewater will be a new norm, especially in historically water-stressed regions (Qu et al., 2013). This has resulted in several technological innovations within the field of wastewater treatment, including advanced oxidation processes, adsorption, and membrane separation (Grassi et al., 2012; Carotenuto et al., 2014) that have been adopted on a case-by-case basis according to processing efficiencies, operational methods, energy requirements, and economic benefit. A promising technological breakthrough is expected from the nanotechnology field, which holds a great potential for advancing water and wastewater treatment with improved treatment efficiency and lower energy consumption, being considered one of the largest engineering innovations since the Industrial Revolution (Wang et al., 2013). Some applications utilize the smoothly scalable size-dependent properties of nanoparticles (NPs) related to their high specific surface area, such as fast dissolution, high reactivity, and strong sorption, whereas others take advantage of their discontinuous properties, such as super-paramagnetism, localized surface plasmon resonance, and quantum confinement effects (Mahdavian and Mirrahimi, 2010; Qu et al., 2013). The nanosize of particles may be of concern about mass transport and excessive pressure drops when applied in fixed-bed or any other flow-through systems, as well as difficulties in separation and reuse, and even possible risk to human health and the ecosystems caused by their potential release into the environment (Zhao et al., 2011).

Polymer-functionalized nanocomposites (PFNCs) incorporate the remarkable features of both NPs and polymers: the unique physical and chemical properties resulting from the large surface area to volume ratios, the high interfacial reactivity of nanofillers, and outstanding mechanical properties and compatibility owing to their polymer matrix (Pan et al., 2009; Zhao et al., 2011), being also amenable to regeneration and reuse (Zhou et al., 2009; Nassar et al.,

\section{PFNCs fabrication}

Direct compounding

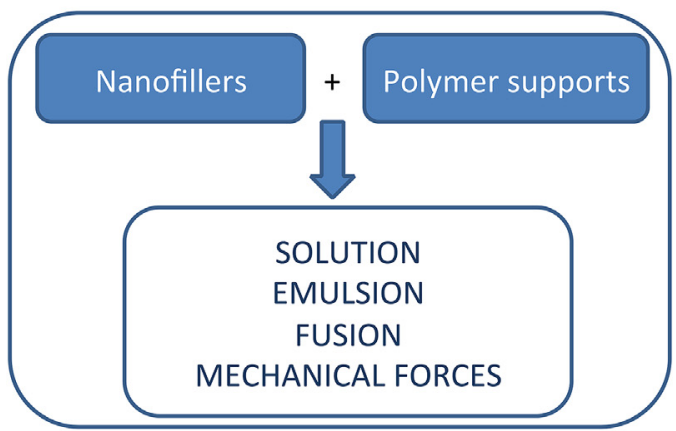

\section{In situ synthesis}

Metal ions are preloaded within polymer matrix to serve as nanoparticle precursors first, where the ions are supposed to distribute uniformly. Then, the precursors are exposed to the corresponding liquid or gas containing $\mathrm{S}^{2-}, \mathrm{OH}^{-}$, or $\mathrm{Se}^{2+}$ to in situ synthesize the target nanoparticles.

Nanoparticles are dispersed into the monomers or precursors of the polymeric hosts. The polymerization of the mixture is obtained under desirable conditions, including addition of appropriate catalyst

Nanoparticles and polymers could be prepared simultaneously by blending the precursors of nanoparticles and the monomers of polymers with an initiator in proper solvent.

Fig. 1. Fabrication methods of PFNCs. 
Table 1

Synthesis of synthetic polymer functionalized nanocomposites (S-PFNCs).

\begin{tabular}{|c|c|c|c|c|}
\hline Polymer matrix & NPs & S-PFNCs & Preparation method & Ref. \\
\hline \multirow[t]{12}{*}{ Polystirene sulfone } & $\begin{array}{l}\text { Hydrated iron oxide } \\
\text { (HFO) }\end{array}$ & PS-(HFO) & In situ synthesis ${ }^{1}$ & Etzel et al., 1997 \\
\hline & $\begin{array}{l}\text { Hydrated iron oxide } \\
\text { (HFO) }\end{array}$ & PS-(HFO) & In situ synthesis ${ }^{1}$ & Cumbal and Sengupta., 2005 \\
\hline & $\begin{array}{l}\text { Hydrated iron oxide } \\
\text { (HFO) }\end{array}$ & PS-(HFO) & In situ synthesis ${ }^{1}$ & De Marco et al., 2003 \\
\hline & $\begin{array}{l}\text { Hydrated iron oxide } \\
\text { (HFO) }\end{array}$ & PS-(HFO) & In situ synthesis ${ }^{1}$ & Sylvester et al., 2007 \\
\hline & $\begin{array}{l}\text { Hydrated iron oxide } \\
\text { (HFO) }\end{array}$ & PS-(HFO) & In situ synthesis ${ }^{1}$ & Möller and Sylvester, 2008 \\
\hline & $\begin{array}{l}\text { Hydrated iron oxide } \\
\text { (HFO) }\end{array}$ & PS-(HFO) & In situ synthesis ${ }^{1}$ & Pan et al., 2010 \\
\hline & $\begin{array}{l}\text { Hydrated iron oxide } \\
\text { (HFO) }\end{array}$ & PS-(HFO) & In situ synthesis ${ }^{1}$ & Qiu et al., 2013 \\
\hline & Hydrous manganese oxide (HMO) & PS-(HMO) & In situ synthesis ${ }^{1}$ & Pan et al., 2007 \\
\hline & $\begin{array}{l}\text { Zirconium hydrogen monothio } \\
\text { phosphate } \mathrm{Zr}\left(\mathrm{HPO}_{3} \mathrm{~S}\right)_{2}\end{array}$ & PS- $\mathrm{Zr}\left(\mathrm{HPO}_{3} \mathrm{~S}\right)_{2}$ & In situ synthesis ${ }^{1}$ & Zhang et al., 2008 \\
\hline & Zirconium phosphate & PS-ZrP & In situ synthesis ${ }^{1}$ & Pan et al., 2006 \\
\hline & Zirconium phosphate & PS-ZrP & Direct compounding & Zhang et al., 2011 \\
\hline & Zirconium Oxide & PS-ZrO 2 & Direct compounding & Zhang et al., 2013 \\
\hline \multirow[t]{6}{*}{ Polystirene chloromethylated } & $\begin{array}{l}\text { Hydrated iron oxide } \\
\text { (HFO) }\end{array}$ & $\mathrm{PCl}-(\mathrm{HFO})$ & Direct compounding & Wang et al., 2011 \\
\hline & $\begin{array}{l}\text { Hydrated iron oxide } \\
\text { (HFO) }\end{array}$ & PCl-(HFO) & In situ synthesis ${ }^{1}$ & Niet at al., 2011 \\
\hline & $\begin{array}{l}\text { Hydrated iron oxide } \\
\text { (HFO) }\end{array}$ & PCl-(HFO) & In situ synthesis ${ }^{1}$ & Qiu et al., 2013 \\
\hline & $\begin{array}{l}\text { Hydrated iron oxide } \\
\text { (HFO) }\end{array}$ & PCl-(HFO) & In situ synthesis ${ }^{1}$ & Nie et al., 2015 \\
\hline & Zirconium phosphate & $\mathrm{PCl}-\mathrm{ZrP}$ & Direct compounding & Zhang et al., 2011 \\
\hline & nano Zero valent Iron & PCl-ZVI & Direct compounding & Jiang et al., 2011 \\
\hline \multirow[t]{3}{*}{ Polystirene with amino group } & Zirconium phosphate & $\mathrm{PN}-\mathrm{ZrP}$ & Direct compounding & Zhang et al., 2011 \\
\hline & nano Zero valent Iron & PN-ZVI & Direct compounding & Jiang et al., 2011 \\
\hline & Hydrous manganese oxide (HMO) & PN-HMO & In situ synthesis ${ }^{1}$ & Pan et al., 2014a \\
\hline Copolymer (Polystyrene + divinylbenzene) & $\begin{array}{l}\text { Hydrated iron oxide } \\
\text { (HFO) }\end{array}$ & CPDB-(HFO) & Direct compounding & Katsoyiannis and Zouboulis, 2002 \\
\hline Acrylic polymer $+\mathrm{N}\left(\mathrm{CH}_{3}\right)_{2}$ & $\begin{array}{l}\text { Hydrated iron oxide } \\
\text { (HFO) }\end{array}$ & $\mathrm{ACP}-\mathrm{N}\left(\mathrm{CH}_{3}\right)_{2}-(\mathrm{HFO})$ & In situ synthesis ${ }^{1}$ & Vatutsina et al., 2007 \\
\hline \multirow[t]{2}{*}{ Polyacrylamide } & $\begin{array}{l}\text { Hydrated iron oxide } \\
\text { (HFO) }\end{array}$ & PA-(HFO) & In situ synthesis ${ }^{2}$ & Manju et al., 2002 \\
\hline & $\begin{array}{l}\text { Magnetite } \\
\left(\mathrm{Fe}_{3} \mathrm{O}_{4}\right)\end{array}$ & $\mathrm{M}-\mathrm{PAM}-\left(\mathrm{Fe}_{3} \mathrm{O}_{4}\right)$ & In situ synthesis ${ }^{1}$ & Zhao et al., 2014 \\
\hline Mercapto-functionalized polymer & $\begin{array}{l}\text { Magnetite } \\
\left(\mathrm{Fe}_{3} \mathrm{O}_{4}\right)\end{array}$ & $\mathrm{MP}-\left(\mathrm{Fe}_{3} \mathrm{O}_{4}\right)$ & In situ synthesis ${ }^{1}$ & Pan et al., 2012 \\
\hline \multirow[t]{3}{*}{ Polyethylenimine } & $\begin{array}{l}\text { Magnetite } \\
\left(\mathrm{Fe}_{3} \mathrm{O}_{4}\right)\end{array}$ & $\mathrm{PEI}-\left(\mathrm{Fe}_{3} \mathrm{O}_{4}\right)$ & Direct compounding & Pang et al., 2011b \\
\hline & $\begin{array}{l}\text { Magnetite } \\
\left(\mathrm{Fe}_{3} \mathrm{O}_{4}\right)+\mathrm{SiO}_{2}\end{array}$ & $\mathrm{PEI}-\left(\mathrm{Fe}_{3} \mathrm{O}_{4}\right)+\mathrm{SiO}_{2}$ & Direct compounding & Pang et al., 2011a \\
\hline & $\mathrm{C}$ & PEI-C & In situ synthesis ${ }^{1}$ & Khaydarov et al., 2010 \\
\hline m-PAA-Na & $\begin{array}{l}\text { Magnetite } \\
\left(\mathrm{Fe}_{3} \mathrm{O}_{4}\right)\end{array}$ & m-PAA-Na- $\left(\mathrm{Fe}_{3} \mathrm{O}_{4}\right)$ & In situ synthesis ${ }^{2}$ & Mahdavian and Mirrahimi, 2010 \\
\hline \multirow[t]{2}{*}{ Ammino-functionalized polymer (TEPA) } & $\begin{array}{l}\text { Magnetite } \\
\left(\mathrm{Fe}_{3} \mathrm{O}_{4}\right)\end{array}$ & TEPA- $\left(\mathrm{Fe}_{3} \mathrm{O}_{4}\right)$ & In situ synthesis ${ }^{2}$ & Zhao et al., 2010 \\
\hline & $\begin{array}{l}\text { Magnetite } \\
\left(\mathrm{Fe}_{3} \mathrm{O}_{4}\right)\end{array}$ & TEPA- $\left(\mathrm{Fe}_{3} \mathrm{O}_{4}\right)$ & In situ synthesis ${ }^{2}$ & Shen et al., 2012 \\
\hline $\begin{array}{l}\text { Poly } \\
\text { (n- vinylcarbazole) }\end{array}$ & Graphene oxide & PnV-G & Direct compounding & Musico et al., 2013 \\
\hline Polypyrrole & Maghemite $\left(\mathrm{Fe}_{2} \mathrm{O}_{3}\right)$ & $\mathrm{PPY} / \gamma-\mathrm{Fe}_{2} \mathrm{O}_{3}$ & In situ synthesis ${ }^{2}$ & Chávez-Guajardo et al., 2015 \\
\hline Polyaniline & Maghemite $\left(\mathrm{Fe}_{2} \mathrm{O}_{3}\right)$ & $\mathrm{PANI} / \gamma-\mathrm{Fe}_{2} \mathrm{O}_{3}$ & In situ synthesis ${ }^{2}$ & Chávez-Guajardo et al., 2015 \\
\hline
\end{tabular}

1,2 These numbers are referred to the preparation methods shown in Fig. 1.

2010). These features made of a promising class of adsorbent materials for metals removal from water and wastewater (Ghorbani and Eisazadeh, 2013). The overall objective of this review focuses on the PFNCs synthesis, characterization, toxicity, adsorption performance, interaction between the polymeric host and the confined nanoparticles (i.e. surface chemistry, pore size distribution and mechanical strength) considering both surface chemistry before and after being confined in the host, including a perspective of new research trends.

\section{Synthesis and characterization of polymer functionalized nanocomposites}

In the last decades, several PFNCs have been fabricated for the adsorptive removal of heavy metals from water and wastewater (DeMarco et al., 2003; Cumbal and Sengupta, 2005; Sylvester et al., 2007; Pan et al., 2010). According to the formation processes, PFNCs can be fabricated by i) grafting NPs into polymer structures, or ii) by anchoring polymers to NPs (Mahdavian and Mirrahimi, 2010). As shown in Fig. 1, two methods can be used for their fabrication: i) direct compounding; and ii) in situ synthesis (Zhao et al., 2011). 
Table 2

Synthesis of Biopolymers functionalized nanocomposites (B-PFNCs).

\begin{tabular}{|c|c|c|c|c|}
\hline Polymer matrix & NPs & B-PNCs & Preparation method & Ref. \\
\hline \multirow[t]{3}{*}{ Calcium alginate } & $\begin{array}{l}\text { Iron oxide } \\
\left(\mathrm{Fe}_{2} \mathrm{O}_{3}\right)\end{array}$ & $\mathrm{CA}-\left(\gamma-\mathrm{Fe}_{2} \mathrm{O}_{3}\right)$ & In situ synthesis ${ }^{2}$ & Bée et al., 2011 \\
\hline & $\begin{array}{l}\text { Hydrated iron oxide } \\
\text { (HFO) }\end{array}$ & CA-(HFO) & Direct compounding & Zouboulis and Katsoyiannis, 2002 \\
\hline & $\begin{array}{l}\text { Magnetite } \\
\left(\mathrm{Fe}_{3} \mathrm{O}_{4}\right)\end{array}$ & $\mathrm{CA}-\left(\mathrm{Fe}_{3} \mathrm{O}_{4}\right)$ & - & Lim et al., 2009 \\
\hline \multirow[t]{2}{*}{ Carboxymethyl- $\beta$-cyclodextrin } & Magnetite & $C-\beta-C D-\left(\mathrm{Fe}_{3} \mathrm{O}_{4}\right)$ & In situ synthesis ${ }^{2}$ & Badruddoza et al., 2011, 2013a, 2013b \\
\hline & $\left(\mathrm{Fe}_{3} \mathrm{O}_{4}\right)$ & $C-\beta-C D-\left(\mathrm{Fe}_{3} \mathrm{O}_{4}\right)$ & - & Yu et al., 2011 \\
\hline \multirow[t]{2}{*}{ Cellulose } & $\begin{array}{l}\text { Hydrated iron oxide } \\
\text { (HFO) }\end{array}$ & $\mathrm{Ce}-(\mathrm{HFO})$ & In situ synthesis ${ }^{2}$ & Guo and Chen 2005 \\
\hline & $\begin{array}{l}\text { Magnetite } \\
\left(\mathrm{Fe}_{3} \mathrm{O}_{4}\right)\end{array}$ & $\mathrm{Ce}-\left(\mathrm{Fe}_{3} \mathrm{O}_{4}\right)$ & In situ synthesis ${ }^{2}$ & Zhu et al., 2011 \\
\hline \multirow[t]{6}{*}{ Chitosan } & $\begin{array}{l}\text { Iron oxide } \\
\left(\mathrm{Fe}_{2} \mathrm{O}_{3}\right)\end{array}$ & $\mathrm{Ch}-\left(\gamma-\mathrm{Fe}_{2} \mathrm{O}_{3}\right)$ & In situ synthesis ${ }^{2}$ & Zhou et al., 2009 \\
\hline & $\begin{array}{l}\text { Magnetite } \\
\left(\mathrm{Fe}_{3} \mathrm{O}_{4}\right)\end{array}$ & $\mathrm{Ch}-\left(\mathrm{Fe}_{3} \mathrm{O}_{4}\right)$ & In situ synthesis ${ }^{2}$ & Tran et al., 2010 \\
\hline & $\begin{array}{l}\text { Magnetite } \\
\left(\mathrm{Fe}_{3} \mathrm{O}_{4}\right)\end{array}$ & $\mathrm{Ch}-\left(\mathrm{Fe}_{3} \mathrm{O}_{4}\right)$ & In situ synthesis ${ }^{2}$ & Chang and Chen, 2005 \\
\hline & $\begin{array}{l}\text { Magnetite } \\
\left(\mathrm{Fe}_{3} \mathrm{O}_{4}\right)\end{array}$ & $\mathrm{Ch}-\left(\mathrm{Fe}_{3} \mathrm{O}_{4}\right)$ & In situ synthesis ${ }^{2}$ & Chang et al., 2006 \\
\hline & $\mathrm{Cu}^{0}$ & $\mathrm{Ch}-\left(\mathrm{Cu}^{0}\right)$ & In situ synthesis ${ }^{2}$ & Wu et al., 2009 \\
\hline & $\mathrm{TiO}_{2}$ & $\mathrm{Ch}-\left(\mathrm{TiO}_{2}\right)$ & $\begin{array}{l}\text { Direct compounding } \\
\text { In situ synthesis }{ }^{2}\end{array}$ & Razzaz et al., 2016 \\
\hline Gum Arabic & $\begin{array}{l}\text { Magnetite } \\
\left(\mathrm{Fe}_{3} \mathrm{O}_{4}\right)\end{array}$ & $\mathrm{GA}-\left(\mathrm{Fe}_{3} \mathrm{O}_{4}\right)$ & In situ synthesis ${ }^{2}$ & Banerjee and Chen, 2007 \\
\hline Poly(methyl methacrylate) grafted Tragacanth gum & $\begin{array}{l}\text { Magnetite } \\
\left(\mathrm{Fe}_{3} \mathrm{O}_{4}\right)\end{array}$ & $\mathrm{P}(\mathrm{MMA})-\mathrm{g}-\mathrm{TG}-\left(\mathrm{Fe}_{3} \mathrm{O}_{4}\right)$ & In situ synthesis ${ }^{2}$ & Sadeghi et al., 2014 \\
\hline Poly-L-cysteine & $\begin{array}{l}\text { Iron oxide } \\
\left(\mathrm{Fe}_{2} \mathrm{O}_{3}\right)\end{array}$ & $\mathrm{PLCy}-\left(\gamma-\mathrm{Fe}_{2} \mathrm{O}_{3}\right)$ & In situ synthesis ${ }^{2}$ & White et al., 2009 \\
\hline
\end{tabular}

${ }^{2}$ The number is referred to the preparation methods shown in Fig. 1.
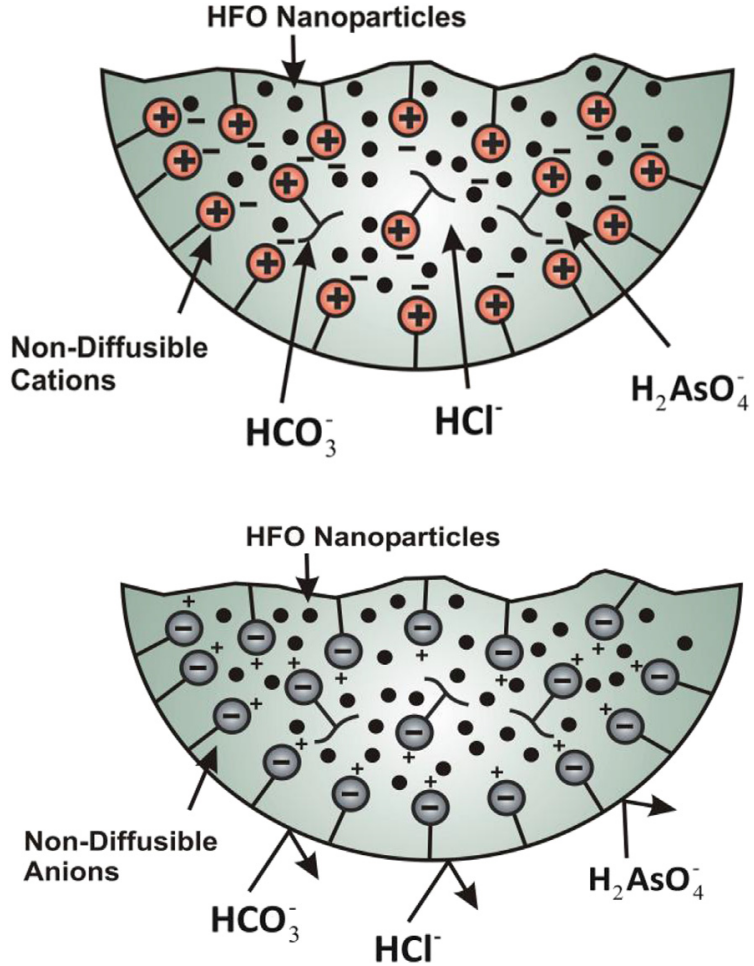

Fig. 2. Schematic representations of the polymeric cation and anion exchangers used on the S-PFNCs Hydrated iron (III) oxide (HFO) (Modified from Cumbal and Sengupta, 2005).

Depending on the host materials, they can be classified as synthetic (S-PFNCs) and biopolymer (B-PFNCs) functionalized nanocomposites. The synthesis processes of S-PFNCs and B-PFNCs as reported in literature are shown in Tables 1 and 2, respectively.

\subsection{S-PFNCS}

Polymeric ion exchangers can be positively or negatively charged (Fig. 2). In a polymeric cation exchanger, negatively charged sulfonic acid groups are covalently attached to the polymer chains, usually polystyrene. Conversely, a polymeric anion exchanger contains a high concentration of non-diffusible positively charged quaternary ammonium functional groups.

Among S-PFNCs, the polystyrene represents the most common host material used to fabricate hybrid adsorbents by grafting NPs into polymers (De Marco et al., 2003; Cumbal and Sengupta, 2005; Pan et al., 2006; Sylvester et al., 2007; Zhang et al., 2008; Sarkar et al., 2011).

The selective sorption of these hybrid polymers toward heavy metals can be explained on the basis of their specific structure including: i) the negatively charged host material, and ii) the dispersion of the NPs onto the inner surface of the polymers. Such sorption preference is mainly attributed to two mechanisms: i) Donnan's membrane effect caused by the negatively charged supporting material, and ii) specific affinity between NPs and heavy metals (Pan et al., 2010; Qiu et al., 2012; Hua et al., 2013a). For instance, Pan et al. (2010) described the specific sorption of heavy metals ions onto D001-(Hydrated Iron (III) Oxide) (HFO) as follows: i) the non-diffusible sulfonate functional groups bound to host D001 are non-specific for heavy metals sorption, but they would result in enhanced permeation and pre-enrichment of metal cations within D001-(HFO) phase prior to sorption onto HFO nanoparticles impregnated in the polymeric framework of D-001 (i.e. favourable for enhanced metal retention by HFO particles); ii) the highly dispersive HFO nanoparticles are expected to exhibit a specific sorption toward heavy metal ions through electrostatic (i.e., ion exchange) and Lewis acid-base (i.e., metal-ligand) 
interactions. Preferable adsorption of $\mathrm{Pb}(\mathrm{II})$ and $\mathrm{Cd}(\mathrm{II})$ over $\mathrm{Ca}(\mathrm{II})$ into D001-Zr(IV) was elucidated on the basis of its specific structure by Hua et al. (2013a). The immobilized sulfonate groups covalently bound to the polystyrene matrix of D001 could enhance preconcentration and permeation of target ions prior to their effective sequestration by the inside oxide particles thanks to the Donnan's effect. Also, the entrapped hydrated $\operatorname{Zr}(\mathrm{IV})$ oxide nanoparticles would provide a specific metal coordination with target ions (i.e., the inner-sphere surface complexation).

Several NPs are used to fabricate this kind of PFNCs, most cases by in situ synthesis (Table 1). HFO, which is innocuous, inexpensive, readily available, and chemically stable over a wide $\mathrm{pH}$ range $2-8$, is the most common type of NPs used to fabricate S-PFNCs, as shown in Table 1.

Amino-functionalized materials are expected to be highly effective for the removal of heavy metals, since the elimination of anionic metal species can be achieved via electrostatic interaction, ion exchange or hydrogen bonding, whereas the removal of the cationic metal species can be performed via coordination with the amino groups (Zhao et al., 2010; Shen et al., 2012).

The main drawback of this kind of granular type adsorbents is related to their recovery once saturated and their potential inhomogeneous dispersion. A large variety of fibrous exchangers based on different polymers has been synthesized and tested in different processes to overcome these limitations (Vatutsina et al., 2007).

As shown in Table 1, different macroporous polystyrene beads bound with different surface groups $\left(-\mathrm{CH}_{2} \mathrm{Cl},-\mathrm{SO}_{3}\right.$, and $\left.-\mathrm{CH}_{2} \mathrm{~N}^{+}\left(\mathrm{CH}_{3}\right)_{3}\right)$ or pore structure have been also tested as host materials for the encapsulation of nZrP (Zhang et al., 2011), nZVI (Jiang et al., 2011), HFO (Wang et al., 2011), and nZrO 2 (Zhang et al., 2013). In general, the presence of charged functional groups $\left(-\mathrm{SO}_{3}^{-}\right.$ and $-\mathrm{CH}_{2} \mathrm{~N}^{+}\left(\mathrm{CH}_{3}\right)_{3}$ ) was more favourable than the neutral $-\mathrm{CH}_{2} \mathrm{Cl}$ group to improve nanoparticles dispersion and, thereby, enhance their reactivity.

\subsection{B-PFNCS}

Several authors reported that magnetic NPs functionalized with biopolymers such as chitosan (Chang and Chen, 2005; Tran et al., 2010; Zhou et al., 2009), alginate (Bée et al., 2011; Lim et al., 2009), gum Arabic (Banerjee and Chen, 2007), cyclodextrins (CDs) (Zhao et al., 2015a) and cellulose (Guo and Chen, 2005) are highly efficient for the removal of toxic metals from aqueous solutions. The main advantages of using iron oxides as composite materials with host materials are the high porosity, magnetic properties, and, usually, good settling properties. Since surface functional group reactions are involved in the sorption processes, higher content of surface functional group sites in a sorbent would lead to a higher sorption capacity for contaminant removal (Nah et al., 2006; Jin et al., 2007). Among biopolymers, chitosan represents a valuable alternative having great potential as a biotechnological solution for wastewater treatment. Chang and Chen (2005) developed a novel B-PFNC by carboxy-methylated chitosan covalently bounded on the surface of $\mathrm{Fe}_{3} \mathrm{O}_{4}$ NPs $\left(\mathrm{Ch}-\left(\mathrm{Fe}_{3} \mathrm{O}_{4}\right)\right)$ via in situ synthesis. Chitosan functionalization can be achieved by using environmentally friendly reagents. Zhou et al. (2009) carried out the surface modification of chitosan-coated magnetic NPs $\left(\mathrm{Ch}-\left(\gamma-\mathrm{Fe}_{2} \mathrm{O}_{3}\right)\right)$ with $\alpha$ ketoglutaric acid ( $\alpha$-KA), which is a natural, inexpensive, harmless and biological reagent containing active functional groups like carboxyl groups. Physical characterization confirmed that the chitosan coating process did not alter significantly the $\gamma-\mathrm{Fe}_{2} \mathrm{O}_{3}$ morphology and the superparamagnetic properties of the $\alpha$-KA-Ch$\left(\gamma-\mathrm{Fe}_{2} \mathrm{O}_{3}\right)$ did not change markedly after coating. Bée et al. (2011) developed a B-PFNC by encapsulation of magnetic functionalized NPs in calcium-alginate beads $\left(\mathrm{CA}-\left(\gamma-\mathrm{Fe}_{2} \mathrm{O}_{3}\right)\right)$, one of the main components of brown seaweed. Bée et al. (2011) reported that the use of nanosized magnetic material improves the adsorption capacity of the alginate beads because of their large surface area and the presence of surface binding groups due to citrate coating. As shown in Table 2, most B-PFNCs were obtained by in situ synthesis, whereas the alginate based ones were produced via direct compounding. A novel B-PFNC was also developed by Banerjee and Chen (2007) treating $\mathrm{Fe}_{3} \mathrm{O}_{4}$ NPs with gum Arabic $\left(\mathrm{GA}-\left(\mathrm{Fe}_{3} \mathrm{O}_{4}\right)\right.$ ). The surface modification did not result in the phase change of $\mathrm{Fe}_{3} \mathrm{O}_{4}$ leading to the formation of secondary particles in the range of 13-67 nm. Spherical $\mathrm{Fe}_{3} \mathrm{O}_{4} /$ bacterial cellulose $\left(\mathrm{Ce}-\left(\mathrm{Fe}_{3} \mathrm{O}_{4}\right)\right)$ B-PFNCs were biosynthesized from Gluconacetobacter xylinum by agitation fermentation (Zhu et al., 2011). The ability of cyclodextrins (CDs), cyclic oligosaccharides consisting of $6(\alpha), 7(\beta), 8(\gamma)$ glucopyranose units linked together via $\alpha(1-4)$ linkages, to complex various metals was found to be highly dependent on the modification of the CDs with suitable functional groups through esterification, oxidation reactions and cross-linking of hydroxyls outside the interior cavity (Norkus, 2009). Carboxymethyl- $\beta$-cyclodextrin (C- $\beta-C D$ ) polymer modified $\left(\mathrm{C}-\beta-\mathrm{CD}-\left(\mathrm{Fe}_{3} \mathrm{O}_{4}\right)\right)$ presented the lowest diameter (8 $\mathrm{nm}$ ) compared to the other B-PFNCs (Badruddoza et al., 2011, 2013a, 2013b). However, in comparison with synthetic complexing agents, such as EDTA and DTPA, (C- $\beta-C D)$ showed weaker metal complexing property, and even its metal removal efficiency has been questioned. In order to overcome these drawbacks, Zhao et al. (2015a) fabricated EDTA- $\beta$-cyclodextrin by reacting $\beta$-cyclodextrin with EDTA as a cross-linker and sodium dihydrogen phosphate (MSP) as a catalyst.

\subsection{Characterization}

Various and complementary multiscale characterization techniques are required for the analysis of structural, morphological and functional properties of PFNCs. The polymer nanocomposite morphology is mainly investigated by a large variety of microscopy techniques, depending on the scale of interest, and ranging from optical to electron microscopy (SEM and TEM, with related diffraction techniques), and scanning probe microscopy (SPM). When PFNCs are magnetic, vibrating sample magnetometry (VSM) is also used for their characterization.

The development of nanocomposite science and technology and the optimization of the functional properties of PFNCs have been possible because of the unparallelled information gathered with the use of these techniques. The information about morphology and structure achieved at the different scales regards not only the structure and distribution of the filler itself, but also the filler-matrix adhesion, and how the presence of the filler impacts on the embedding polymer matrix properties (Michler, 2008).

Currently, there is a growing interest focused on the use of specialized microscopy techniques such as electron tomography and the low voltage approach due to their ability to provide quantitative information about the adhesion and dispersion of the filler in the embedding polymeric matrix (Khare and Burris, 2010). When in situ investigations are applicable and possible, specific information can be obtained on the filler matrix interaction properties thus increasing the comprehension of the mechanisms behind the characteristics enhancement observed for nanocomposites. Other commonly and widely used characterization tools are: i) X-ray diffraction (XRD) for the structural analysis, ii) Fourier transform infrared (FTIR), and Raman spectroscopy X-ray photoelectron spectroscopy (XPS) and energy dispersive X-ray spectrometry (EDX) for the study of the modes of surface groups and the nature of chemical bonds, iii) thermal analysis for the determination of water uptake (TGA), and iv) ionic exchange capacity. 


\section{Removal of metals by PFNCs}

The basic principle for the use of PFNCs for metals removal is adsorption. Overall, various effects contribute determining the whole efficacy of PFNCs action.

\subsection{Adsorption isotherms}

The investigation of the interactions between adsorbate and adsorbent showed that adsorption isotherms are the most significant. Adsorption isotherms are functional expressions that correlate the amount of solute adsorbed per unit weight of the adsorbent and the concentration of the adsorbate in the bulk solution at a given temperature under equilibrium conditions. The most used models describing the sorption equilibrium of metal ions were developed by Langmuir (Langmuir, 1918; Eq. (1)), Freundlich (Freundlich, 1906; Eq. (2)) and Brunauer, Emmet and Teller (BET), Redlich-Peterson (Eq. (3)) and Dubinin-Radushkevich(D-R), Temkin (4). The Langmuir adsorption model is valid for single-layer adsorption, whereas BET model uses isotherms reflecting apparent multilayer adsorption. Thus, when the limit of adsorption is a monolayer, BET isotherms reduce to Langmuir model. Temkin isotherm contains a factor that explicitly takes into account adsorbent-adsorbate interactions. By ignoring the extremely low and large value of concentrations, the model assumes that heat of adsorption (function of temperature) of all molecules in the layer would decrease linearly rather than logarithmic with coverage. Dubinin-Radushkevich isotherm is generally applied to express the adsorption mechanism with a Gaussian energy distribution onto a heterogeneous surface. The model has often successfully fitted high solute activities as well as the intermediate range of concentrations data well.

$\frac{C_{e}}{q_{e}}=\frac{C_{e}}{q_{m}}+\frac{1}{q_{m} K_{L}}$

$\ln q_{e}=\ln K_{F}+\left(\frac{1}{n}\right) \ln C_{e}$

$q_{e}=\frac{P C_{e}}{1+\alpha C_{e}^{\beta}}$

$q_{e}=\frac{R T}{b} \ln k_{T}+\frac{R T}{b} \ln C_{e}$

In Eq. (1), $q_{e}$ is the amount of adsorbate adsorbed per mass of adsorbent at equilibrium ( $\left.\mathrm{mg} \mathrm{g}^{-1}\right), C_{e}$ is the equilibrium concentration of adsorbate in aqueous solution ( $\left.\mathrm{mg} \mathrm{L}^{-1}\right), q_{m}$ is the monolayer adsorption capacity at equilibrium $\left(\mathrm{mg} \mathrm{g}^{-1}\right)$ and $K_{L}$ the Langmuir equilibrium constant. The Freundlich model assumes adsorption can occur in multiple layers, so that saturation cannot occur. In Eq. (2), $K_{F}$ is an index of adsorption capacity, and $n$ is the Freundlich constant (index of adsorption intensity or surface heterogeneity). .

In Eq. (3) $\mathrm{P}\left(\mathrm{L} \mathrm{mg}^{-1}\right)$ and $\alpha\left(\mathrm{L} \mathrm{mg}^{-1}\right)$ are the isotherm constants of Redlich-Peterson isotherm model and $\beta$ is the exponential term which lies between 0 and 1 . In Eq. (4) $R$ is the gas constant (8.341 $\mathrm{J} \mathrm{mol}^{-1} \mathrm{~K}^{-1}$ ), $\mathrm{T}$ is the absolute temperature $(\mathrm{K}), \mathrm{K}_{\mathrm{T}}$ is the equilibrium binding constant $\left(\mathrm{L} \mathrm{g}^{-1}\right)$, and $\mathrm{b}$ is a constant related to the heat of adsorption $\left(\mathrm{J} \mathrm{mol}^{-1}\right)$.

To determine whether the adsorption is favourable, a dimensionless constant separation factor or equilibrium parameter $R_{L}$ is defined based on Eq. (5) (Weber and Chakravorti, 1974):

$$
R_{L}=\frac{1}{1+K_{L} C_{i}}
$$

where, $C_{i}\left(\mathrm{mg} \mathrm{L}^{-1}\right)$ is the initial metal concentration. The value of $R_{L}$ value indicates whether the type of the isotherm is favourable $\left(0<R_{L}<1\right)$, unfavourable $\left(R_{L}>1\right)$, linear $\left(R_{L}=1\right)$, or irreversible $\left(R_{L}=0\right)$.

Badruddoza et al. (2013b) reported $R_{L}$ values between 0 and 1 for the Langmuir isotherm, and Freundlich adsorption intensity variables ( $n$ values) $>2$ supporting the favourable adsorption of metal ions by $\mathrm{C}-\beta-\mathrm{CD}-\left(\mathrm{Fe}_{3} \mathrm{O}_{4}\right)$. $R_{L}$ values also between 0 and 1 were determined for nano magnetic polymer adsorbents coupled with different diamino-groups for any initial concentration of $\mathrm{Cr}(\mathrm{VI})$ (Zhao et al., 2010). For an initial concentration of $\mathrm{Cr}(\mathrm{VI})$ of $50 \mathrm{mg} \mathrm{L}^{-1}$, the polymer nano-adsorbents $R_{L}$ values were $0.11,0.04$, 0.21 , and 0.14 for EDA- $\left(\mathrm{Fe}_{3} \mathrm{O}_{4}\right)$, DETA- $\left(\mathrm{Fe}_{3} \mathrm{O}_{4}\right)$, TETA- $\left(\mathrm{Fe}_{3} \mathrm{O}_{4}\right)$ and TEPA- $\left(\mathrm{Fe}_{3} \mathrm{O}_{4}\right)$, respectively. The adsorption isotherms followed the Langmuir rules. The isotherm parameters are summarised in Tables 3 and 4 for S-PFNCs and B-PFNCs, respectively. The adsorption isotherms are one of the most useful data to understand the mechanism of adsorption and the isotherm characteristics are needed before the interpretation of the kinetics of the adsorption process. Pseudo-first-order (Eq. (6)) and pseudo-second-order (Eq. (7)) models are commonly used to describe the adsorption kinetic data (Pan et al., 2012):

$\log \left(q_{e}-q_{t}\right)=\log q_{e}-\left(\frac{k_{1}}{2.303}\right) t$

$\frac{t}{q_{t}}=\frac{1}{k_{t} q_{e^{2}}}+\left(\frac{1}{q_{e}}\right) t$

where $\mathrm{q}_{\mathrm{t}}$ is the adsorption capacity at time $\mathrm{t}\left(\mathrm{mg} \mathrm{g}^{-1}\right), \mathrm{k}_{1}\left(\mathrm{~min}^{-1}\right), \mathrm{k}_{\mathrm{t}}$ $\left(\mathrm{g} \mathrm{mg}^{-1} \mathrm{~min}^{-1}\right.$ ) are the adsorption rate constants.

\subsection{Effect of polymer matrix and NPs composition}

Cumbal and Sengupta (2005) observed that, despite greater HFO content, the sorbents based on cation-exchanger were practically unable to remove $A s(V)$ compared to the anion-exchanger based sorbents. This phenomenon was explained by the Donnan's exclusion effect, which is essentially an extension of the second law of thermodynamics, concerning in a specific way the completely ionized electrolytes in a heterogeneous system.

The magnetic properties of the composite materials and their possible result in higher adsorption capacities towards metals is currently under discussion (Bibak, 1994). Davis and Bhatnagar (1995) have shown the ratio between the magnetic "core" and the "shell" plays an important role: i) a low ratio of the magnetic oxide (the "core") may decrease a magnetic response, while ii) a low ratio of polymer component (the "shell") may lead to a decrease on the adsorption capacity.

The adsorption of $\mathrm{Hg}^{2+}$ by $\mathrm{MP}-\left(\mathrm{Fe}_{3} \mathrm{O}_{4}\right)$ seems to be highly related to the content of $\mathrm{Fe}_{3} \mathrm{O}_{4}$ magnetic core in the adsorbents (Pan et al., 2012). The maximum adsorption capacity increased from $129.9 \mathrm{mg} \mathrm{g}^{-1}$ to $256.4 \mathrm{mg} \mathrm{g}^{-1}$ with an increase from 0 to $1.0 \mathrm{~g}$ of $\mathrm{Fe}_{3} \mathrm{O}_{4}$ used for the MP- $\left(\mathrm{Fe}_{3} \mathrm{O}_{4}\right)$ preparation, whereas a decrease from $256.4 \mathrm{mg} \mathrm{g}^{-1}$ to $158.7 \mathrm{mg} \mathrm{g}^{-1}$ was obtained when increasing the $\mathrm{Fe}_{3} \mathrm{O}_{4}$ quantity from $1.0 \mathrm{~g}$ to $2.0 \mathrm{~g}$. The optimized content of the magnetic core on the MP- $\left(\mathrm{Fe}_{3} \mathrm{O}_{4}\right)$ was $5.88 \%$ of $\mathrm{Fe}_{3} \mathrm{O}_{4}$. Since the MP0 with the largest amount of $-\mathrm{SH}$ groups $\left(9.17 \mathrm{mmol} \mathrm{g}^{-1}\right)$, and the $\mathrm{MP}-\left(\mathrm{Fe}_{3} \mathrm{O}_{4}\right)$ with $2.0 \mathrm{~g}\left(\mathrm{Fe}_{3} \mathrm{O}_{4}\right)$ showed the lowest adsorption capacities, and the adsorption capacity of bare $\mathrm{Fe}_{3} \mathrm{O}_{4}$ to $\mathrm{Hg}$ (II) was found to be $51.5 \mathrm{mg} \mathrm{g}^{-1}$, the authors concluded that the adsorption 
Table 3

Behaviour of S-PFNCs for metal removal.

\begin{tabular}{|c|c|c|c|c|c|c|c|}
\hline Metals & $\begin{array}{l}\text { S-PFNPs see } \\
\text { Table } 1\end{array}$ & $\mathrm{pH}$ & $\begin{array}{l}\mathrm{C}_{\mathrm{o}} \\
{\left[\mathrm{mg} \mathrm{L}^{-1}\right]}\end{array}$ & Adsorption capacities & $\begin{array}{l}\text { Removal } \\
(\%)\end{array}$ & Adsorption constants & References \\
\hline \multirow[t]{6}{*}{$\mathrm{As}(\mathrm{III})$} & PS-(HFO) & 7.2 & 0.100 & $<10$ ppb within $2000 \mathrm{BV}$ & $>90$ & - & De Marco et al., 2003 \\
\hline & PS-(HFO) & & 100 & $\begin{array}{l}<10 \mathrm{ppb} \text { within } \\
12000 \mathrm{BV}\end{array}$ & $>90$ & - & $\begin{array}{l}\text { Cumbal and Sengupta, } \\
2005\end{array}$ \\
\hline & PS-(HFO)-39a & 7 & 10 & 178.7 mg g-1 & 60 & - & Nie et al., 2015 \\
\hline & PS-(HFO)-78 & 6.5 & & 197.7 mg g-1 & 70 & & \\
\hline & PS-(HFO)-350 & 6 & & $220.5 \mathrm{mg} \mathrm{g}-1$ & 80 & & \\
\hline & $\begin{array}{l}\mathrm{ACP}-\mathrm{N}\left(\mathrm{CH}_{3}\right)_{2-}^{-} \\
(\mathrm{HFO})\end{array}$ & 9 & 60 & $<10$ ppb within $10000 \mathrm{BV}$ & 90 & $\begin{array}{l}\mathrm{K}_{\mathrm{L}}=1.52 \mathrm{~L} \mathrm{mmol}^{-1} \\
\mathrm{~K}_{\mathrm{F}}=0.58 \mathrm{~L} \mathrm{mmol}^{-1}\end{array}$ & Vatutsina et al., 2007 \\
\hline \multirow[t]{11}{*}{$\operatorname{As}(\mathrm{V})$} & PS-(HFO) & & 100 & $<0.5 \mathrm{ppm}$ & $>95$ & - & Etzel et al., 1997 \\
\hline & PS-(HFO) & 7.2 & 0.050 & $<10 \mathrm{ppb}$ within $4000 \mathrm{BV}$ & $>80$ & & De Marco et al., 2003 \\
\hline & PS-(HFO) & & 0.100 & $\begin{array}{l}<10 \mathrm{ppb} \text { within } \\
10000 \mathrm{BV}\end{array}$ & $>90$ & - & $\begin{array}{l}\text { Cumbal and Sengupta, } \\
2005\end{array}$ \\
\hline & PS-(HFO) & 8.16 & 0.023 & $<0.5 \mathrm{ppb}$ within $33196 \mathrm{BV}$ & $>98$ & - & Sylvester et al., 2007 \\
\hline & PS-(HFO) & & 0.020 & $<10$ ppb within $17500 \mathrm{BV}$ & $>50$ & - & Möller and Sylvester, \\
\hline & & & 0.300 & $<10$ ppb within $3500 \mathrm{BV}$ & $>96$ & & 2008 \\
\hline & PS-(HFO)-39a & 3 & 10 & $233.9 \mathrm{mg} \mathrm{g}-1$ & 75 & - & Nie et al., 2015 \\
\hline & PS-(HFO)-78 & & & $268.0 \mathrm{mg} g-1$ & 85 & & \\
\hline & PS-(HFO)-350 & & & $326.4 \mathrm{mg}$ g-1 & 95 & & \\
\hline & CPDB-(HFO) & & 0.100 & $<10$ ppb within $65 \mathrm{BV}$ & 90 & & $\begin{array}{l}\text { Katsoyiannis and } \\
\text { Zouboulis, } 2002\end{array}$ \\
\hline & $\begin{array}{l}\mathrm{ACP}-\mathrm{N}\left(\mathrm{CH}_{3}\right)_{2-}^{-} \\
\text {(HFO) }\end{array}$ & 5.64 & 60 & $<10$ ppb within $10000 \mathrm{BV}$ & 90 & $\begin{array}{l}\mathrm{K}_{\mathrm{L}}=3.23 \mathrm{~L} \mathrm{mmol}^{-1} \\
\mathrm{~K}_{\mathrm{F}}=0.68 \mathrm{~L} \mathrm{mmol}^{-1}\end{array}$ & Vatutsina et al., 2007 \\
\hline \multirow[t]{7}{*}{$\mathrm{Cd}(\mathrm{II})$} & $\mathrm{PA}-(\mathrm{HFO})$ & $5-6$ & 25 & $21.03 \mathrm{mg} \mathrm{g}^{-1}$ & 81 & $\mathrm{~K}_{\mathrm{L}}=0.0206 \mathrm{~L} \mathrm{mg}^{-1}$ & Manju et al., 2002 \\
\hline & PS-(HFO) & - & 1 & $<5$ ppb within $7000 \mathrm{BV}$ & $>99$ & - & Pan et al., 2007 \\
\hline & PS-HMO & - & & $\begin{array}{l}\text { sorption capacities increased by } 50-300 \% \\
\text { compared to host exchangers }\end{array}$ & - & $\begin{array}{l}\mathrm{K}_{\mathrm{d}} \text { increased by } 20-800 \text { times as } \\
\text { compared to host exchangers }\end{array}$ & Pan et al., 2008 \\
\hline & $\mathrm{PS}-\mathrm{Zr}\left(\mathrm{HPO}_{3} \mathrm{~S}\right)$ & - & 45 & $<0.09 \mathrm{mg} \mathrm{L}^{-1}$ within $1600 \mathrm{BV}$ & $>99$ & - & Zhang et al., 2008 \\
\hline & $\begin{array}{l}\text { m-PAA-Na- } \\
\left(\mathrm{Fe}_{3} \mathrm{O}_{4}\right)\end{array}$ & 8 & 1.8 & $5.0 \mathrm{mg} \mathrm{g}^{-1}$ & - & - & $\begin{array}{l}\text { Mahdavian and } \\
\text { Mirrahimi, } 2010\end{array}$ \\
\hline & PEI-C & 6 & 3 & $<0.005$ ppm & 99 & - & Khaydarov et al., 2010 \\
\hline & $\begin{array}{l}\text { PEI- } \\
\left(\mathrm{Fe}_{3} \mathrm{O}_{4}\right)+\mathrm{SiO}_{2}\end{array}$ & 6.5 & 100 & $105.2 \mathrm{mg} \mathrm{g}^{-1}$ & 78 & $\begin{array}{l}\mathrm{K}_{\mathrm{L}}=0.0290 \mathrm{~L} \mathrm{mg}^{-1} \\
\mathrm{~K}_{\mathrm{F}}=11.545 \mathrm{Lg}^{-1}\end{array}$ & Pang et al., 2011a \\
\hline \multirow[t]{7}{*}{$\mathrm{Cr}(\mathrm{VI})$} & $\mathrm{PEI}-\left(\mathrm{Fe}_{3} \mathrm{O}_{4}\right)$ & $2-3$ & - & $83.33 \mathrm{mg} \mathrm{g}^{-1}$ & 95 & $\begin{array}{l}\mathrm{K}_{\mathrm{L}}=0.125 \mathrm{~L} \mathrm{mg}^{-1} \\
\mathrm{~K}_{\mathrm{F}}=20.85 \mathrm{~L} \mathrm{~g}^{-1}\end{array}$ & Pang et al., 2011b \\
\hline & TEPA- $\left(\mathrm{Fe}_{3} \mathrm{O}_{4}\right)$ & - & - & $370.37 \mathrm{mg} \mathrm{g}^{-1}$ & - & $\mathrm{K}_{\mathrm{L}}=0.1233 \mathrm{~L} \mathrm{mg}^{-1}$ & Zhao et al., 2010 \\
\hline & TEPA- $\left(\mathrm{Fe}_{3} \mathrm{O}_{4}\right)$ & 2 & 50 & - & 99 & - & Shen et al., 2012 \\
\hline & & & 500 & & 73 & & \\
\hline & & & 1000 & & 42 & & \\
\hline & $\mathrm{PPY} / \gamma-\mathrm{Fe}_{2} \mathrm{O}_{3}$ & 2 & 100 & 208.8 & 52 & $\begin{array}{l}\mathrm{K}_{\mathrm{L}}=2.3 \mathrm{~L} \mathrm{mg}^{-1} \\
\mathrm{~K}_{\mathrm{F}}=106.7 \mathrm{mg} \mathrm{g}^{-1}\end{array}$ & $\begin{array}{l}\text { Chávez-Guajardo } \\
\text { et al., } 2015\end{array}$ \\
\hline & $\mathrm{PANI} / \gamma-\mathrm{Fe}_{2} \mathrm{O}_{3}$ & 2 & 100 & 195.7 & 48 & $\begin{array}{l}\mathrm{K}_{\mathrm{L}}=3.0 \mathrm{~L} \mathrm{mg}^{-1} \\
\mathrm{~K}_{\mathrm{F}}=100.8 \mathrm{mg} \mathrm{g}^{-1}\end{array}$ & $\begin{array}{l}\text { Chávez-Guajardo } \\
\text { et al., } 2015\end{array}$ \\
\hline \multirow[t]{9}{*}{$\mathrm{Cu}(\mathrm{II})$} & PS-(HFO) & - & 1 & $<5$ ppb within $7000 \mathrm{BV}$ & $>99$ & - & Pan et al., 2007 \\
\hline & $\begin{array}{l}\mathrm{PEI}- \\
\left(\mathrm{Fe}_{3} \mathrm{O}_{4}\right)+\mathrm{SiO}_{2}\end{array}$ & 6.5 & 100 & $157.8 \mathrm{mg} \mathrm{g}^{-1}$ & 98 & $\begin{array}{l}\mathrm{K}_{\mathrm{L}}=0.0318 \mathrm{~L} \mathrm{mg}^{-1} \\
\mathrm{~K}_{\mathrm{F}}=42.561 \mathrm{~L} \mathrm{~g} \mathrm{~g}^{-1}\end{array}$ & Pang et al., 2011a \\
\hline & PEI-C & 6 & 10 & $<0.005$ ppm & 99 & - & Khaydarov et al., 2010 \\
\hline & $\begin{array}{l}\text { m-PAA-Na- } \\
\left(\mathrm{Fe}_{3} \mathrm{O}_{4}\right)\end{array}$ & 8 & 18 & $27.0 \mathrm{mg} \mathrm{g}^{-1}$ & - & - & $\begin{array}{l}\text { Mahdavian and } \\
\text { Mirrahimi, } 2010\end{array}$ \\
\hline & TEPA- $\left(\mathrm{Fe}_{3} \mathrm{O}_{4}\right)$ & 4 & 10 & $116.80 \mathrm{mg} \mathrm{g}^{-1}$ & 99.85 & $\mathrm{~K}_{\mathrm{L}}=0.4009 \mathrm{~L} \mathrm{mg}^{-1}$ & Shen et al., 2012 \\
\hline & & & 100 & & 78.51 & & \\
\hline & & & 300 & & 17.66 & & \\
\hline & $\mathrm{PPY} / \gamma-\mathrm{Fe}_{2} \mathrm{O}_{3}$ & 5.5 & 100 & 170.7 & 47 & $\begin{array}{l}\mathrm{K}_{\mathrm{L}}=1.4 \mathrm{~L} \mathrm{mg}^{-1} \\
\mathrm{~K}_{\mathrm{F}}=66.5 \mathrm{mg} \mathrm{g}^{-1}\end{array}$ & $\begin{array}{l}\text { Chávez-Guajardo } \\
\text { et al., } 2015\end{array}$ \\
\hline & $\mathrm{PANI} / \gamma-\mathrm{Fe}_{2} \mathrm{O}_{3}$ & 5.5 & 100 & 106.8 & 27 & $\begin{array}{l}\mathrm{K}_{\mathrm{L}}=1.7 \mathrm{~L} \mathrm{mg}^{-1} \\
\mathrm{~K}_{\mathrm{F}}=54.4 \mathrm{mg} \mathrm{g}^{-1}\end{array}$ & $\begin{array}{l}\text { Chávez-Guajardo } \\
\text { et al., } 2015\end{array}$ \\
\hline \multirow[t]{2}{*}{$\mathrm{Hg}(\mathrm{II})$} & PA-(HFO) & 5 & 25 & $21.38 \mathrm{mg} g-1$ & 85 & $\mathrm{~K}_{\mathrm{L}}=0.0246 \mathrm{~L} \mathrm{mg}-1$ & Manju et al., 2002 \\
\hline & $\mathrm{MP}-\left(\mathrm{Fe}_{3} \mathrm{O}_{4}\right)$ & $2-6$ & - & $256.4 \mathrm{mg} \mathrm{g}^{-1}$ & - & $\begin{array}{l}\mathrm{K}_{\mathrm{L}}=0.0585 \mathrm{~L} \mathrm{mg}^{-1} \\
\mathrm{~K}_{\mathrm{F}}=50.54 \mathrm{~L} \mathrm{~g}^{-1}\end{array}$ & Pan et al., 2012 \\
\hline $\mathrm{Ni}(\mathrm{II})$ & $\begin{array}{l}\text { m-PAA-Na- } \\
\left(\mathrm{Fe}_{3} \mathrm{O}_{4}\right)\end{array}$ & & 18 & $25.0 \mathrm{mg} \mathrm{g}^{-1}$ & - & - & $\begin{array}{l}\text { Mahdavian and } \\
\text { Mirrahimi, } 2010\end{array}$ \\
\hline \multirow[t]{7}{*}{$\mathrm{Pb}(\mathrm{II})$} & PS-HMO & & & $\begin{array}{l}\text { sorption capacities increased by } 50-300 \% \\
\text { compared to host exchangers }\end{array}$ & - & $\begin{array}{l}\mathrm{K}_{\mathrm{d}} \text { increased by } 20-800 \text { times as } \\
\text { compared to host exchangers }\end{array}$ & Pan et al., 2008 \\
\hline & PA-(HFO) & 6 & 25 & $23.79 \mathrm{mg} \mathrm{g}^{-1}$ & 96 & $\mathrm{~K}_{\mathrm{L}}=0.0250 \mathrm{~L} \mathrm{mg}^{-1}$ & Manju et al., 2002 \\
\hline & $\mathrm{PS}-\mathrm{Zr}\left(\mathrm{HPO}_{3} \mathrm{~S}\right)$ & & 80 & $<0.01 \mathrm{mg} \mathrm{L}^{-1}$ within $1600 \mathrm{BV}$ & $>99$ & - & Zhang et al., 2008 \\
\hline & PS-ZrP & & 0.5 & $<0.05$ ppm within $2000 \mathrm{BV}$ & 98 & - & Pan et al., 2006 \\
\hline & PS-(HFO) & & 1 & $<5$ ppb within $7000 \mathrm{BV}$ & $>99$ & - & Pan et al., 2010 \\
\hline & $\begin{array}{l}\text { m-PAA-Na- } \\
\left(\mathrm{Fe}_{3} \mathrm{O}_{4}\right)\end{array}$ & 8 & 18 & $40.0 \mathrm{mg} \mathrm{g}^{-1}$ & - & - & $\begin{array}{l}\text { Mahdavian and } \\
\text { Mirrahimi, } 2010\end{array}$ \\
\hline & PnV-G & 7 & $5-300$ & $982.86 \mathrm{mg} \mathrm{g}^{-1}$ & 97 & $\mathrm{~K}_{\mathrm{L}}=0.0187 \mathrm{~L} \mathrm{mg}^{-1}$ & Musico et al., 2013 \\
\hline \multirow[t]{3}{*}{$\mathrm{Zn}(\mathrm{II})$} & PS-HMO & & & $\begin{array}{l}\text { sorption capacities increased by } 50-300 \% \\
\text { compared to host exchangers }\end{array}$ & - & $\begin{array}{l}\mathrm{K}_{\mathrm{d}} \text { increased by } 20-800 \text { times as } \\
\text { compared to host exchangers }\end{array}$ & Pan et al., 2007 \\
\hline & $\mathrm{PS}-\mathrm{Zr}\left(\mathrm{HPO}_{3} \mathrm{~S}\right)_{2}$ & & 15 & $<0.06 \mathrm{mg} \mathrm{L}^{-1}$ within $120 \mathrm{BV}$ & $>99$ & - & Zhang et al., 2008 \\
\hline & PEI-C & 6 & 5 & $<0.010 \mathrm{ppm}$ & 99 & - & Khaydarov et al., 2010 \\
\hline
\end{tabular}


Table 3 (continued)

\begin{tabular}{|c|c|c|c|c|c|c|c|}
\hline Metals & $\begin{array}{l}\text { S-PFNPs see } \\
\text { Table } 1\end{array}$ & $\mathrm{pH}$ & $\begin{array}{l}\mathrm{C}_{\mathrm{o}} \\
{\left[\mathrm{mg} \mathrm{L}^{-1}\right]}\end{array}$ & Adsorption capacities & $\begin{array}{l}\text { Removal } \\
(\%)\end{array}$ & Adsorption constants & References \\
\hline & $\begin{array}{l}\text { PEI- } \\
\left(\mathrm{Fe}_{3} \mathrm{O}_{4}\right)+\mathrm{SiO}_{2}\end{array}$ & 6.5 & 100 & $138.8 \mathrm{mg} \mathrm{g}^{-1}$ & $80 \%$ & $\begin{array}{l}\mathrm{K}_{\mathrm{L}}=0.0245 \mathrm{~L} \mathrm{mg}^{-1} \\
\mathrm{~K}_{\mathrm{F}}=33.986 \mathrm{~L} \mathrm{~g}^{-1}\end{array}$ & Pang et al., 2011a \\
\hline $\mathrm{Se}(\mathrm{IV})$ & PS-(HFO) & & 100 & $<0.5 \mathrm{ppm}$ & $>99$ & - & Etzel et al., 1997 \\
\hline
\end{tabular}

${ }^{a}$ PS hosts of surface areas 39,78 and $350 \mathrm{~m}^{2} / \mathrm{g}$.

capacity of $\mathrm{Hg}$ (II) may be an integrated result of both the amount of mercapto-groups and $\mathrm{Fe}_{3} \mathrm{O}_{4}$ content. There might be some cooperative interactions between MP groups and $\mathrm{Fe}_{3} \mathrm{O}_{4}$.

Similarly, the amount of iron as oxyhydroxide was also a crucial factor for the arsenic adsorption capacity (Guo and Chen, 2005). Katsoyiannis and Zouboulis (2002) observed that the adsorption capacity of CPDB-(HFO) increased with an increasing amount of coated iron oxide.

\subsection{Effect of $p H$}

The $\mathrm{pH}$ affects the functional groups deprotonation determining the strength of the complexation or adsorption of the metals and metalloids. A first approach to evaluate the adsorption capacity of adsorbents towards metals is the determination of the $\mathrm{pH}$ at the point of zero charge (PZC). The overall surface charge on a PFNC becomes positive when the $\mathrm{pH}$ of the solution is below the PZC inhibiting the approach of the positively charged metal ions (electrostatic repulsion) (Zhou et al., 2009). Guo and Chen (2005) studied the influence of $\mathrm{pH}$ in the range (4-11) on the adsorption of $\mathrm{AsO}_{3}^{3-}$ and $\mathrm{AsO}_{4}^{3-}\left(300 \mathrm{mg} \mathrm{L}^{-1}\right)$. In general, the removal rate of $\mathrm{AsO}_{4}^{3-}$ decreased with increasing $\mathrm{pH}$. The percentage removal of $\mathrm{AsO}_{4}^{3-}$ by $\mathrm{Ce}-(\mathrm{HFO})$ decreased from $96.2 \%$ to $52.6 \%$ when changing the $\mathrm{pH}$ from 4 to 11 . The percentage of $\mathrm{AsO}_{3}^{3-}$ removal by $\mathrm{Ce}-(\mathrm{HFO})$ was higher than that for $\mathrm{AsO}_{4}^{3-}$ (90\% for $\mathrm{pH}$ values between 5 and 10) except when $\mathrm{pH}$ was $4-5$. Optimal $\mathrm{AsO}_{3}^{3-}$ adsorption by $\mathrm{Ce}-$ (HFO) was found at $\mathrm{pH} 7-9$ where the percentage removed was above $95 \%$ (Table 4 ).

The adsorption capacities of $\mathrm{MP}-\left(\mathrm{Fe}_{3} \mathrm{O}_{4}\right)$ for $\mathrm{Hg}^{2+}$ increased with increasing the $\mathrm{pH}$, reaching a steady-state at $\mathrm{pH}$ between 4 and 6 (Pan et al., 2012). This could be explained by the PZC of MP- $\left(\mathrm{Fe}_{3} \mathrm{O}_{4}\right)$ at $\mathrm{pH} 2.03-2.72$, indicating that repulsion takes place when there is the presence of cations such as $\mathrm{Hg}^{2+}, \mathrm{HgOH}^{+}$and $\mathrm{HgCl}^{+}$, thus, resulting in low adsorption capacities at $\mathrm{pH}<2.7$.

\subsection{Effect of temperature and contact time}

Some studies (Chang and Chen, 2005; Badruddoza et al., 2011, 2013a) reported that the adsorption capacity of metal ions decreases with increasing temperature, indicating that adsorption is an exothermic process being the electrostatic interaction between metal ions and PFNCs lower at higher temperatures. Also the contact time between the adsorbent and adsorbate is an important parameter to design the adsorption processes.

The time at which the equilibrium is reached may drastically change depending on adsorption sites on the exterior of the adsorbents: $100 \mathrm{~min}$ for $\mathrm{Cd}^{2+}, \mathrm{Cu}^{2+}$, and $\mathrm{Pb}^{2+}$ adsorption by D001(HFO) (Pan et al., 2010), 240 min for $\mathrm{Pb}^{2+}$ adsorption by CA- $(\gamma-$ $\mathrm{Fe}_{2} \mathrm{O}_{3}$ ) (Bée et al., 2011), 2 min for $\mathrm{Cu}^{2+}$ adsorption rate by GA$\left(\mathrm{Fe}_{3} \mathrm{O}_{4}\right)$ (Banerjee and Chen, 2007). Kinetic studies showed that the adsorption of $\mathrm{Hg}(\mathrm{II})$ by $\mathrm{MP}-\left(\mathrm{Fe}_{3} \mathrm{O}_{4}\right)$ at different content of the $\left(\mathrm{Fe}_{3} \mathrm{O}_{4}\right)$ and $\mathrm{pH}$ values (2,3 and 5) followed a pseudo-second-order model, suggesting a chemisorption process (Pan et al., 2012). A time of $90 \mathrm{~min}$ was needed for the MP-0 (MP-functionalized polymer adsorbents without a $\mathrm{Fe}_{3} \mathrm{O}_{4}$ core) to reach adsorption equilibrium, while only 10 min for $\mathrm{MP}-\left(\mathrm{Fe}_{3} \mathrm{O}_{4}\right)$ containing a certain amount of $\mathrm{Fe}_{3} \mathrm{O}_{4}$ were needed. At decreasing values of $\mathrm{pH}$, the adsorption equilibrium time increased, i.e., the equilibrium time was found to be 10,30 , and $60 \mathrm{~min}$ when adsorption $\mathrm{pH}$ was set at 5.0,3.0, and 2.0 , respectively. This may be due to the formation of $-\mathrm{S}-\mathrm{Hg}^{+}$at low $\mathrm{pH}$ values limiting the further ingress of positive charged species such as $\mathrm{Hg}^{2+}$ due to the electrostatic barriers, thus delaying the adsorption equilibrium time. While at $\mathrm{pH}=5.0$, no electrostatic barriers occurred and the equilibrium time decreased accordingly.

The adsorption of $\mathrm{Tl}(\mathrm{I})$ versus contact time for D001-(HMO) was very quick at the beginning, and was followed by a gradual adsorption approaching equilibrium within $1 \mathrm{~h}$ (Pan et al., 2014b). The high correlation coefficients indicated that $\mathrm{Tl}(\mathrm{I})$ adsorption can be well represented by the pseudo-first-order model. Similar kinetic behaviour was also observed for lead ion removal by polymerbased zirconium phosphate (Pan et al., 2007). The sorption of $\mathrm{Pb}(\mathrm{II})$, $\mathrm{Cu}(\mathrm{II})$, and $\mathrm{Cd}(\mathrm{II})$ on HFO-001 was studied as a function of contact time at $\mathrm{pH}=5.0$ and $30^{\circ} \mathrm{C}$ as shown in Fig. 3 (Pan et al., 2010) An initial fast step was completed within $30 \mathrm{~min}$ and followed by a slower second stage. The sorption equilibrium was achieved after 100 min. Similar results were reported by Zhao et al. (2014) for $\mathrm{Cd}(\mathrm{II}), \mathrm{Pb}(\mathrm{II}), \mathrm{Co}(\mathrm{II})$ and $\mathrm{Ni}(\mathrm{II})$ removal by $\mathrm{M}-\mathrm{PAM}-\left(\mathrm{Fe}_{3} \mathrm{O}_{4}\right)$. The maximum adsorption of all metals was attained after $120 \mathrm{~min}$, $120 \mathrm{~min}, 360 \mathrm{~min}$ and $180 \mathrm{~min}$, respectively.

\subsection{Effect of initial concentration of metal ions and adsorbent dose}

Zhu et al. (2011) reported that when the concentrations of $\mathrm{Mn}^{2+}$ and $\mathrm{Cr}^{3+}$ were $<60 \mathrm{mg} \mathrm{mL}^{-1}$, the adsorbed quantities on $\mathrm{Ce}-\left(\mathrm{Fe}_{3} \mathrm{O}_{4}\right)$ resulted proportional to their concentrations. While the concentration of $\mathrm{Mn}^{2+}$ and $\mathrm{Cr}^{3+}$ was $>60 \mathrm{mg} / \mathrm{mL}$, the adsorption capacity decreased from $46 \%$ to $33 \%$ for $\mathrm{Mn}^{2+}$ and from $43 \%$ to $25 \%$ for $\mathrm{Cr}^{3+}$. Similarly, the percentage removal of $\mathrm{Cu}^{2+}$ decreased with the increase of the initial $\mathrm{Cu}^{2+}$ ion concentration from 100 to $400 \mathrm{mg} \mathrm{L}^{-1}$ (Zhou et al., 2009). This was expected due to the fact that for a fixed adsorbent dosage, the total available adsorption sites are limited, thus leading to a decrease, corresponding to an increased initial adsorbate concentration, in the percentage removal of the adsorbate.

Chávez-Guajardo et al. (2015) reported that when interacting $2 \mathrm{mg}$ of $\mathrm{PPY} / \gamma-\mathrm{Fe}_{2} \mathrm{O}_{3} \mathrm{MNC}$ with $10 \mathrm{~mL}$ of a $50 \mathrm{mg} \mathrm{L}^{-1} \mathrm{Cr}(\mathrm{VI}) \mathrm{so}-$ lution, the limit for $\mathrm{Cr}(\mathrm{VI})$ removal was determined as $82 \%$ (corresponding to $0.41 \mathrm{mg}$ ). However, the same amount of $\mathrm{PPY} / \gamma-\mathrm{Fe}_{2} \mathrm{O}_{3}$ MNC was able to remove only $52.2 \%$ of the total amount of $\mathrm{Cr}(\mathrm{VI})$ present in $10 \mathrm{~mL}$ of a solution containing $100 \mathrm{mg} \mathrm{L}^{-1} \mathrm{Cr}$ (VI) solution (corresponding to a total of $0.52 \mathrm{mg}$ ).

An optimum adsorbent dose is required to maximize the interactions between the metal ions and the available adsorption sites on the adsorbent. Zhou et al. (2009) observed that the increase of $\mathrm{Ch}-\left(\gamma-\mathrm{Fe}_{2} \mathrm{O}_{3}\right)$ from 0 to $7 \mathrm{~g} \mathrm{~L}^{-1}$ resulted in an increase of the $\mathrm{Cu}^{2+}$ removal efficiency (99\%), whereas higher concentrations lead to an adsorption decrease (Table 4). Evidently, this effect is dependent on external factors such as the stirring of the solution. In fact, the increase of the PFNC concentration with no change of the agitation speed can result in aggregation of the PFNC lowering the 
Table 4

Behaviour of S B-PFNCs adsorption.

\begin{tabular}{|c|c|c|c|c|c|c|c|}
\hline Metals & $\begin{array}{l}\text { B-PFNCs } \\
\text { see Table } 2\end{array}$ & Optimum pH & $\mathrm{C}_{\mathrm{o}}\left[\mathrm{mg} \mathrm{L}^{-1}\right]$ & Adsorption capacities & Removal (\%) & Adsorption constants & References \\
\hline \multirow[t]{3}{*}{$\mathrm{As}(\mathrm{III})$} & CA-(HFO) & 7 & 0.05 & $<10$ ppb within $45 \mathrm{BV}$ & $>95$ & - & $\begin{array}{l}\text { Zouboulis and Katsoyiannis, } \\
2002\end{array}$ \\
\hline & $\mathrm{Ce}-(\mathrm{HFO})$ & $7-9$ & 7.5 & $99.6 \mathrm{mg} \mathrm{g}^{-1}$ & 95 & $\mathrm{~K}_{\mathrm{L}}=0.120 \mathrm{~L} \mathrm{mg}^{-1}$ & Guo and Chen, 2005 \\
\hline & $\mathrm{PLCy}-\left(\gamma-\mathrm{Fe}_{2} \mathrm{O}_{3}\right)$ & $\begin{array}{l}7 \\
(4-9)\end{array}$ & 1 & $25.6 \mathrm{mg} \mathrm{g}^{-1}$ & 22 & - & White et al., 2009 \\
\hline \multirow[t]{2}{*}{$\mathrm{As}(\mathrm{V})$} & $\mathrm{CA}-(\mathrm{HFO})$ & 7 & 0.05 & $<10$ ppb within $230 \mathrm{BV}$ & $>95$ & - & $\begin{array}{l}\text { Zouboulis and Katsoyiannis, } \\
2002\end{array}$ \\
\hline & $\mathrm{Ce}-(\mathrm{HFO})$ & $\begin{array}{l}7 \\
(5-11)\end{array}$ & 7.5 & $33.2 \mathrm{mg} \mathrm{g}^{-1}$ & 90 & $\mathrm{~K}_{\mathrm{L}}=2.29 \mathrm{~L} \mathrm{mg}^{-1}$ & Guo and Chen, 2005 \\
\hline $\mathrm{Au}(\mathrm{III})$ & $\mathrm{Ch}-\left(\mathrm{Fe}_{3} \mathrm{O}_{4}\right)$ & $\begin{array}{l}2 \\
(2-10)\end{array}$ & $\begin{array}{l}1039 \\
(200-3000)\end{array}$ & $59.52 \mathrm{mg} \mathrm{g}^{-1}$ & & $\begin{array}{l}\mathrm{K}_{\mathrm{L}}=0.066 \mathrm{~L} \mathrm{mg}^{-1} \\
\mathrm{~K}_{\mathrm{F}}=13.14 \mathrm{~L} \mathrm{~g}^{-1}\end{array}$ & Chang and Chen, 2005 \\
\hline \multirow[t]{7}{*}{$\mathrm{Cu}(\mathrm{II})$} & $\mathrm{CA}-\left(\mathrm{Fe}_{3} \mathrm{O}_{4}\right)$ & $\begin{array}{l}5 \\
(2-6)\end{array}$ & $\begin{array}{l}1 \\
(1-6)\end{array}$ & $60 \mathrm{mg} \mathrm{g}^{-1}$ & & $\mathrm{~K}_{\mathrm{L}}=1.43 \mathrm{~L} \mathrm{mg}^{-1}$ & Lim et al., 2009 \\
\hline & $\mathrm{C}-\beta-\mathrm{CD}-\left(\mathrm{Fe}_{3} \mathrm{O}_{4}\right)$ & $\begin{array}{l}6 \\
(2-6)\end{array}$ & $(50-200)$ & $47.2 \mathrm{mg} \mathrm{g}^{-1}$ & & $\begin{array}{l}\mathrm{K}_{\mathrm{L}}=0.0237 \mathrm{~L} \mathrm{mg}^{-1} \\
\mathrm{~K}_{\mathrm{F}}=7.064 \mathrm{~L} \mathrm{~g}^{-1}\end{array}$ & Badruddoza et al., 2011 \\
\hline & $\mathrm{Ch}-\left(\gamma-\mathrm{Fe}_{2} \mathrm{O}_{3}\right)$ & $\begin{array}{l}6 \\
(2-8)\end{array}$ & $\begin{array}{l}200 \\
(100-400)\end{array}$ & $96.15 \mathrm{mg} \mathrm{g}^{-1}$ & $55-99$ & $\begin{array}{l}\mathrm{K}_{\mathrm{L}}=0.0493 \mathrm{~L} \mathrm{mg}^{-1} \\
\mathrm{~K}_{\mathrm{F}}=16.406 \mathrm{~L} \mathrm{~g}^{-1}\end{array}$ & Zhou et al., 2009 \\
\hline & $\mathrm{Ch}-\left(\mathrm{Fe}_{3} \mathrm{O}_{4}\right)$ & $\begin{array}{l}5 \\
(2-5)\end{array}$ & $\begin{array}{l}1150 \\
(200-1150)\end{array}$ & $21.5 \mathrm{mg} \mathrm{g}^{-1}$ & & $\mathrm{~K}_{\mathrm{L}}=0.0165 \mathrm{~L} \mathrm{mg}^{-1}$ & Chang and Chen, 2005 \\
\hline & $\mathrm{GA}-\left(\mathrm{Fe}_{3} \mathrm{O}_{4}\right)$ & 5.1 & 200 & $38.5 \mathrm{mg} \mathrm{g}^{-1}$ & & $\mathrm{~K}_{\mathrm{L}}=0.012 \mathrm{~L} \mathrm{mg}^{-1}$ & Banerjee and Chen, 2007 \\
\hline & $\mathrm{PLCy}-\left(\gamma-\mathrm{Fe}_{2} \mathrm{O}_{3}\right)$ & $\begin{array}{l}7 \\
(4-9)\end{array}$ & 1 & $43.3 \mathrm{mg} \mathrm{g}^{-1}$ & 60 & - & White et al., 2009 \\
\hline & $\mathrm{Ch}-\left(\mathrm{TiO}_{2}\right)$ & 6 & 50 & $\begin{array}{l}526.50 \mathrm{mg} \mathrm{g}^{-1} \mathrm{a} \\
715.70 \mathrm{mg} \mathrm{g}^{-1(2)}\end{array}$ & & $\begin{array}{l}\mathrm{K}_{\mathrm{L}}=0.02551^{\mathrm{a}} \mathrm{L} \mathrm{mg}^{-1} \\
\mathrm{~K}_{\mathrm{L}}=0.03192^{\mathrm{b}} \mathrm{L} \mathrm{mg}^{-1} \\
\mathrm{~K}_{\mathrm{F}}=86.04{ }^{\mathrm{a}} \mathrm{mg} \mathrm{g}^{-1} \\
\mathrm{~K}_{\mathrm{F}}=117.0{ }^{\mathrm{b}} \mathrm{mg} \mathrm{g}^{-1}\end{array}$ & Razzaz et al., 2016 \\
\hline \multirow[t]{2}{*}{ Cd (II) } & $\mathrm{C}-\beta-\mathrm{C}-\left(\mathrm{Fe}_{3} \mathrm{O}_{4}\right)$ & $5.5-6$ & 300 & $27.7 \mathrm{mg} \mathrm{g}^{-1}$ & 55.9 & $\begin{array}{l}\mathrm{K}_{\mathrm{L}}=0.214 \mathrm{~L} \mathrm{mg}^{-1} \\
\mathrm{~K}_{\mathrm{F}}=17.64 \mathrm{~L} \mathrm{~g}^{-1}\end{array}$ & Badruddoza et al., 2013a \\
\hline & $\mathrm{PLCy}-\left(\gamma-\mathrm{Fe}_{2} \mathrm{O}_{3}\right)$ & $\begin{array}{l}7 \\
(4-9)\end{array}$ & 1 & $43.3 \mathrm{mg} \mathrm{g}^{-1}$ & 71 & - & White et al., 2009 \\
\hline $\mathrm{Cr}(\mathrm{III})$ & $\mathrm{Ce}-\left(\mathrm{Fe}_{3} \mathrm{O}_{4}\right)$ & - & $\begin{array}{l}0-100 \\
100-200\end{array}$ & $25 \mathrm{mg} \mathrm{g}^{-1}$ & $\begin{array}{l}35 \\
25\end{array}$ & - & Zhu et al., 2011 \\
\hline \multirow[t]{2}{*}{$\mathrm{Cr}(\mathrm{VI})$} & $\mathrm{Ch}-\left(\mathrm{Cu}^{0}\right)$ & 4.85 & $\begin{array}{l}5 \\
50\end{array}$ & $\begin{array}{l}3.96 \mathrm{mg} \mathrm{g}^{-1} \\
47.8 \mathrm{mg} \mathrm{g}^{-1}\end{array}$ & & - & Wu et al, 2009 \\
\hline & $\mathrm{P}(\mathrm{MMA})-\mathrm{g}-\mathrm{TG}-\left(\mathrm{Fe}_{3} \mathrm{O}_{4}\right)$ & 5.5 & $<20$ & $7.64 \mathrm{mg} \mathrm{g}^{-1}$ & 97.8 & $\begin{array}{l}\mathrm{K}_{\mathrm{L}}=0.00183 \mathrm{~L} \mathrm{mg}^{-1} \\
\mathrm{~K}_{\mathrm{F}}=4.4 \mathrm{mg} \mathrm{g}^{-1}\end{array}$ & Sadeghi et al., 2014 \\
\hline $\mathrm{Mn}(\mathrm{II})$ & $\mathrm{Ce}-\left(\mathrm{Fe}_{3} \mathrm{O}_{4}\right)$ & - & $\begin{array}{l}0-100 \\
100-200\end{array}$ & $33 \mathrm{mg} \mathrm{g}^{-1}$ & $\begin{array}{l}46 \\
33\end{array}$ & - & Zhu et al., 2011 \\
\hline \multirow[t]{3}{*}{$\mathrm{Ni}(\mathrm{II})$} & $\mathrm{C}-\beta-\mathrm{CD}-\left(\mathrm{Fe}_{3} \mathrm{O}_{4}\right)$ & $5.5-6$ & 300 & $13.2 \mathrm{mg} \mathrm{g}^{-1}$ & 24.3 & $\begin{array}{l}\mathrm{K}_{\mathrm{L}}=0.043 \mathrm{~L} \mathrm{mg}^{-1} \\
\mathrm{~K}_{\mathrm{F}}=2.39 \mathrm{~L} \mathrm{~g}^{-1}\end{array}$ & Badruddoza et al., 2013a \\
\hline & $\mathrm{Ch}-\left(\mathrm{Fe}_{3} \mathrm{O}_{4}\right)$ & $\begin{array}{l}6 \\
(4-6)\end{array}$ & $\begin{array}{l}70 \\
(50-80)\end{array}$ & $52.55 \mathrm{mg} \mathrm{g}^{-1}$ & $>75$ & $\mathrm{~K}_{\mathrm{L}}=1.3448 \mathrm{~L} \mathrm{mg}^{-1}$ & Tran et al., 2010 \\
\hline & PLCy- $\left(\gamma-\mathrm{Fe}_{2} \mathrm{O}_{3}\right)$ & $\begin{array}{l}7 \\
(4-9)\end{array}$ & 1 & $32.8 \mathrm{mg} \mathrm{g}^{-1}$ & 89 & 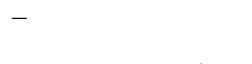 & White et al., 2009 \\
\hline \multirow[t]{7}{*}{$\mathrm{Pb}(\mathrm{II})$} & $\mathrm{CA}-\left(\gamma-\mathrm{Fe}_{2} \mathrm{O}_{3}\right)$ & $\begin{array}{l}4.7 \\
(1-6)\end{array}$ & $\begin{array}{l}51.8-4972.8 \\
1502.2\end{array}$ & $97.4 \mathrm{mg} \mathrm{g}^{-1}$ & & $\mathrm{~K}_{\mathrm{L}}=0.076 \mathrm{~L} \mathrm{mg}^{-1}$ & Bèe et al, 2011 \\
\hline & $\mathrm{Ce}-\left(\mathrm{Fe}_{3} \mathrm{O}_{4}\right)$ & & $\begin{array}{l}0-100 \\
100-200\end{array}$ & $\begin{array}{l}65 \mathrm{mg} \mathrm{g}^{-1} \\
52 \mathrm{mg} \mathrm{g}^{-1}\end{array}$ & $\begin{array}{l}90 \\
65\end{array}$ & - & Zhu et al., 2011 \\
\hline & $\mathrm{Ch}-\left(\mathrm{Fe}_{3} \mathrm{O}_{4}\right)$ & $\begin{array}{l}6 \\
(4-6)\end{array}$ & $\begin{array}{l}70 \\
(50-80)\end{array}$ & $63.33 \mathrm{mg} \mathrm{g}^{-1}$ & $>90$ & $\mathrm{~K}_{\mathrm{L}}=0.1097 \mathrm{~L} \mathrm{mg}^{-1}$ & Tran et al., 2010 \\
\hline & $\mathrm{C}-\beta-\mathrm{CD}-\left(\mathrm{Fe}_{3} \mathrm{O}_{4}\right)$ & $5.5-6$ & 200 & $52.20 \mathrm{mg} \mathrm{g}^{-1}$ & & $\begin{array}{l}\mathrm{K}_{\mathrm{L}}=0.208 \mathrm{~L} \mathrm{mg}^{-1} \\
\mathrm{~K}_{\mathrm{F}}=16.43 \mathrm{~L} \mathrm{~g}^{-1}\end{array}$ & Badruddoza et al., 2013b \\
\hline & $\mathrm{C}-\beta-\mathrm{CD}-\left(\mathrm{Fe}_{3} \mathrm{O}_{4}\right)$ & $5.5-6$ & 300 & $64.5 \mathrm{mg} \mathrm{g}^{-1}$ & 99.5 & $\begin{array}{l}\mathrm{K}_{\mathrm{L}}=0.417 \mathrm{~L} \mathrm{mg}^{-1} \\
\mathrm{~K}_{\mathrm{F}}=25.82 \mathrm{~L} \mathrm{~g}^{-1}\end{array}$ & Badruddoza et al., 2013b \\
\hline & $\mathrm{PLCy}-\left(\gamma-\mathrm{Fe}_{2} \mathrm{O}_{3}\right)$ & $\begin{array}{l}7 \\
(4-9)\end{array}$ & 1 & $14.7 \mathrm{mg} \mathrm{g}^{-1}$ & 67 & - & White et al., 2009 \\
\hline & $\mathrm{Ch}-\left(\mathrm{TiO}_{2}\right)$ & 6 & 50 & $\begin{array}{l}475.50 \mathrm{mg} \mathrm{g}^{-1 \mathrm{a}} \\
579.10 \mathrm{mg} \mathrm{g}^{-1} \mathrm{~b}\end{array}$ & - & $\begin{array}{l}\mathrm{K}_{\mathrm{L}}=0.02618^{\mathrm{a}} \mathrm{L} \mathrm{mg}^{-1} \\
\mathrm{~K}_{\mathrm{L}}=0.02642^{\mathrm{b}} \mathrm{L} \mathrm{mg}^{-1} \\
\mathrm{~K}_{\mathrm{F}}=75.22{ }^{\mathrm{a}} \mathrm{mg} \mathrm{g}^{-1} \\
\mathrm{~K}_{\mathrm{F}}=88.4{ }^{\mathrm{b}} \mathrm{mg} \mathrm{g}^{-1}\end{array}$ & Razzaz et al., 2016 \\
\hline $\mathrm{Zn}$ & $\mathrm{PLCy}-\left(\gamma-\mathrm{Fe}_{2} \mathrm{O}_{3}\right)$ & $\begin{array}{l}7 \\
(4-9)\end{array}$ & 1 & $24.1 \mathrm{mg} \mathrm{g}^{-1}$ & 50 & - & White et al., 2009 \\
\hline
\end{tabular}

${ }^{\text {a }}$ In situ synthesis ${ }^{2}$.

b Direct compounding.

availability of the functional groups for complexation of the metal ions. The solution ion concentration drops to a lower value at higher adsorbent dose, and the system reaches equilibrium at lower concentrations of adsorbed metal indicating that the adsorption sites remain unsaturated.

\subsection{Effect of coexisting ions}

Coexisting ions in solution can compete with metals for the adsorption sites affecting the removal process (Guo and Chen, 2005; Vatutsina et al., 2007; Pan et al., 2012). The major anionic antagonistic components are phosphate $\left(\mathrm{PO}_{4}^{2-}\right)$, silicate $\left(\mathrm{SiO}_{4}^{4-}\right)$, 


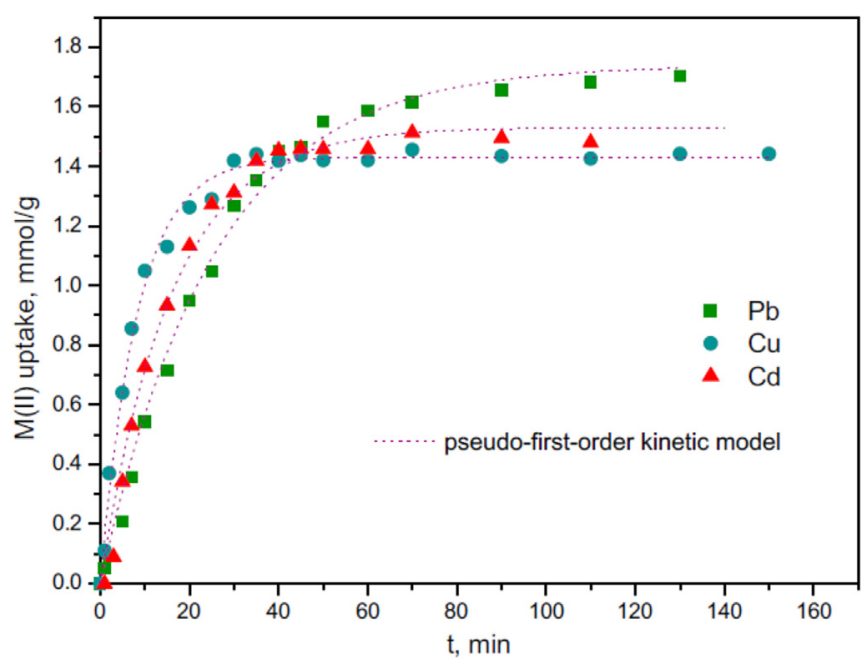

Fig. 3. Sorption kinetics of heavy metal ions onto HFO-001 at pH 5.0 and $303 \mathrm{~K} .1 .00 \mathrm{~g}$ sorbent was added into $1000 \mathrm{~mL}$ solution containing $500 \mathrm{ppm}$ of each heavy meta (Adopted from Pan et al., 2010).

and sulphate $\left(\mathrm{SO}_{4}^{-}\right)$, which are usually present in groundwater streams. According to Katsoyiannis and Zouboulis (2002), phosphate concentrations $<50 \mathrm{mg} \mathrm{L}^{-1}$ do not show any significant inhibition on As removal by CPDB-(HFO), whereas for concentrations above $200 \mathrm{mg} \mathrm{L}^{-1} \mathrm{PO}_{4}^{2-}$ strongly compete with As for the available adsorption sites even impeding its removal when attaining concentrations of $400 \mathrm{mg} \mathrm{L}^{-1}$. In presence of $\mathrm{SiO}_{4}^{4-}$, the removal rate of $\mathrm{AsO}_{3}^{3-}$ by $\mathrm{Ce}-(\mathrm{HFO})$ can decrease up to $85 \%$, and to a lower extent due to the interference of $\mathrm{PO}_{4}^{2-}$ (Guo and Chen, 2005). Comparing the behaviour of PCl-(HFO) and PS-(HFO), Qiu et al. (2012) reported that $\mathrm{Cu}$ adsorption on $\mathrm{PCl}$-(HFO) was markedly promoted by introducing sulphate. . Besides the electrostatic effects, the formation of $\mathrm{Cu}-\mathrm{SO}_{4}$ ternary complexes also accounted for the enhanced $\mathrm{Cu}$ sorption on both bulky HFO and hybrid HFO sorbents in presence of sulphate. These results indicated that the effect of counter ion ligands on metal adsorption to hybrid iron oxides was largely dependent on the surface properties of host materials. The effect of $\mathrm{Ca}^{2+}, \mathrm{Mg}^{2+}$, and $\mathrm{Na}^{+}$on the adsorption of $\mathrm{Hg}^{2+}$ seems to be less significant since these cations have less affinity to - $\mathrm{SH}$ groups than $\mathrm{Hg}^{2+}$ as predicted by HSAB theory (Pan et al., 2012). Oxalate is supposed to affect the applicability of the HFO based composites for environmental remediation because it would enhance HFO dissolution. However, Qiu et al. (2013) reported that the dissolution rate was considerable lower for $\mathrm{PCl}$-(HFO) and PS-(HFO) compared to the bare HFO, probably due to the slower oxalate adsorption. The polymeric host PS was more favourable than $\mathrm{PCl}$ for HFO dispersion inside, resulting in higher oxalate uptake and faster dissolution of PS-(HFO) than PCl-(HFO).

\subsection{Interaction between polymeric host and nanoparticles}

To date, few studies have been presented concerning the interplay between the host materials and the immobilized inorganic nanoparticles (Cumbal and Sengupta, 2005; Blaney et al., 2007; Sarkar and Sengupta, 2010). The host materials for larger particle size greatly improve the permeability and separation of the resulting nanocomposites, helping to inhibit the aggregation of inorganic nanoparticles encapsulated therein due to the steric effect caused by their rigid matrix. Tests carried out on different macroporous polystyrene beads bound with different surface groups $\left(-\mathrm{CH}_{2} \mathrm{Cl},-\mathrm{SO}_{3}\right.$, and $\left.-\mathrm{CH}_{2} \mathrm{~N}^{+}\left(\mathrm{CH}_{3}\right)_{3}\right)$ or pore structure as host materials for the encapsulation of nZrP (Zhang et al., 2011), nZVI (Jiang et al., 2011), HFO (Wang et al., 2011), and nZrO 2 (Zhang et al., 2013) proved that polymer surface groups and the pore size greatly affect PFNCs size and capacity. The maximum compressive strengths of all the resulting nanocomposites were greatly improved. Another topic of interest in the evaluation of the interaction between the polymeric host and the nanoparticles is represented by the difference in surface chemistry of NPs before and after being confined in the host. For instance, hydrous manganese oxide (HMO) is generally negatively charged at circumneutral $\mathrm{pH}$ and cannot effectively remove anionic pollutants such as phosphate. Nevertheless after its immobilization within a polystyrene

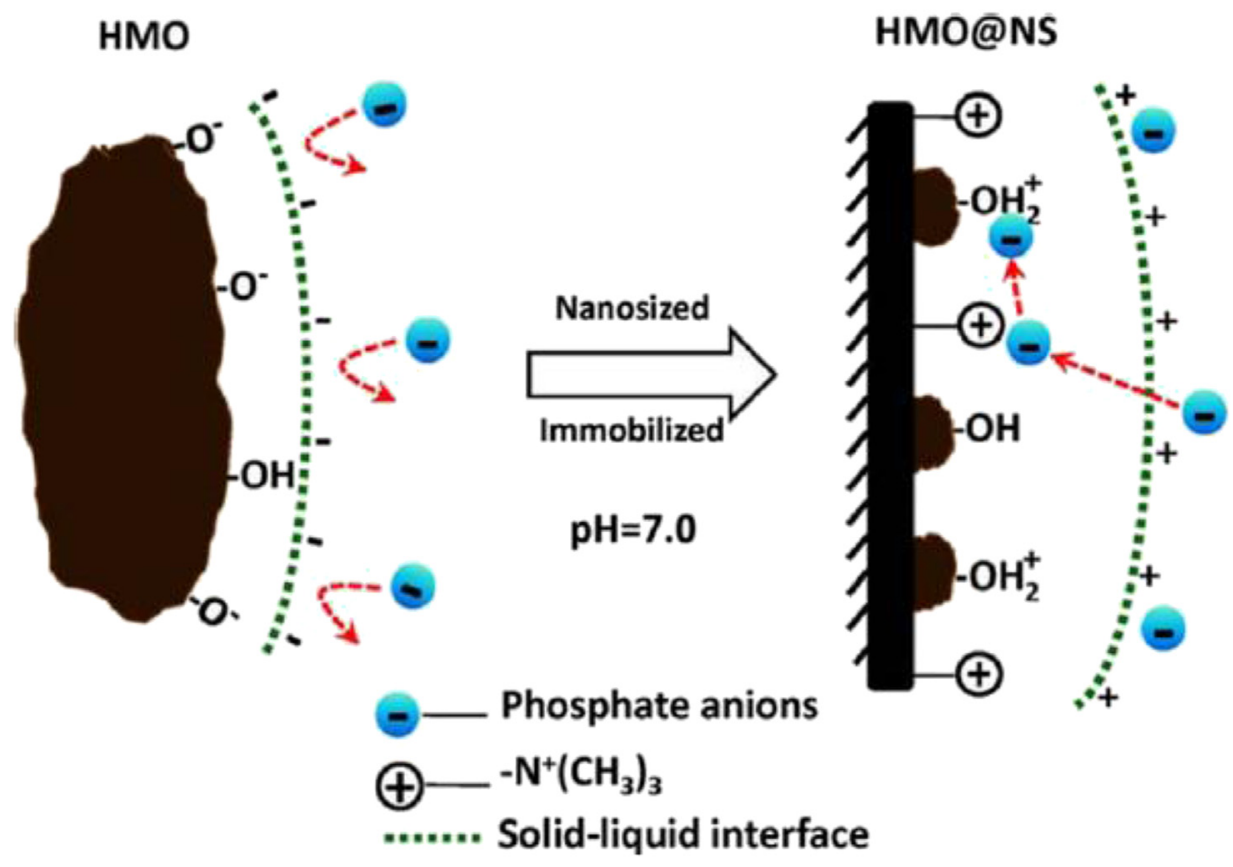

Fig. 4. Schematic illustration of phosphate adsorption by HMO before and after being loaded into NS (Adopted from Pan et al., 2014a). 
anion exchanger (NS), as shown in Fig. 4, the resulting nanocomposite HMO@NS exhibited substantially enhanced phosphate removal efficiency in presence of sulphate, chloride, and nitrate at greater levels (Pan et al., 2014a). Recently, Nie et al. (2013) revealed that encapsulating HFO particles into a polystyrene host would result in the variation of the acid base properties of the inside HFO and, consequently, affecting its sorption toward arsenate and copper ions. Further, Nie et al. (2015) highlighted the pore size effect of the host on the intrinsic surface properties of HFO after being encapsulated inside different polymeric hosts. The smaller the HFO loaded in the polymeric hosts of higher surface area, the lower the $\mathrm{pH}_{\mathrm{PZC}}$ value of the resulting composite and the weaker affinity for $\mathrm{H}^{+}$and the stronger the affinity for $\mathrm{OH}^{-}$.

\subsection{Regeneration and reuse}

Hybrid ion exchangers can offer advantages over other adsorbents due to their chemical stability, and durable physical structure and amenability to regeneration and reuse (Sarkar et al., 2011). Regeneration of adsorbents has two main objectives: i) to restore the adsorption capacity of exhausted adsorbents, and ii) to recover valuable metals present in the adsorbed phase. The first aim can be attained under acidic conditions; the $\mathrm{H}^{+}$ions protonate the adsorbent surface, i.e., the carboxyl groups $(-\mathrm{COOH})$, resulting in desorption of the positively charged metal ions (i.e., competition between the $\mathrm{H}^{+}$and the $\mathrm{M}^{\mathrm{z}+}$ for the $-\mathrm{COO}^{-}$groups). The regeneration efficiency of $\mathrm{Ch}-\left(\gamma-\mathrm{Fe}_{2} \mathrm{O}_{3}\right)$ was tested (Zhou et al., 2009) by using four different eluents, $\mathrm{Na}_{2} \mathrm{EDTA}, \mathrm{HCl}, \mathrm{CH}_{3} \mathrm{COOH}$ and citric acid, at two different concentrations, 25 and $100 \mathrm{mmol} \mathrm{L}^{-1}$. The obtained results showed that $100 \mathrm{mmol} \mathrm{L}^{-1}$ of $\mathrm{Na}_{2}$ EDTA had the highest efficiency (91.5\%), due to its larger complexation capacity towards the metal ions. Yu et al. (2011) showed the highest efficiency of $\mathrm{Na}_{2}$ EDTA to desorb $\mathrm{Pb}^{2+}$ ions when added to $\mathrm{C}-\beta-\mathrm{CD}$ $\left(\mathrm{Fe}_{3} \mathrm{O}_{4}\right)$. Also, Nassar (2010) showed that $\mathrm{HNO}_{3}$ and $\mathrm{Na}_{2}$ EDTA solutions have very high desorption efficiencies for $\mathrm{Pb}^{2+}$ from CDpoly-MNPs (96.0 and $94.2 \%$ recovery, respectively), whereas $\mathrm{H}_{3} \mathrm{PO}_{4}$ was found to be a better eluent for $\mathrm{Cd}^{2+}$ and $\mathrm{Ni}^{2+}$ desorption (with a recovery of 61.8 and $82.7 \%$, respectively).

The desorption data of adsorbed $\mathrm{Pb}^{2+}$ ions from magnetic alginate beads by elution with $2 \mathrm{~mol} \mathrm{~L}^{-1} \mathrm{HNO}_{3}$ showed that $88.9 \%$ of the $\mathrm{Pb}^{2+}$ ions were released in the solution after 30 min (Bée et al., 2011). The adsorption capacity of the magsorbent was maintained at the same level even after 5 elution cycles, indicating that the magsorbent can be reused for the removal of heavy metals (Nassar, 2010).

Zhu et al. (2011) also showed that spherical $\mathrm{Fe}_{3} \mathrm{O}_{4} /$ bacterial cellulose nanocomposites $\left(\mathrm{Fe}_{3} \mathrm{O}_{4} / \mathrm{BC}\right)$ could be regenerated by using sodium citrate and reused for further adsorption of metals.

\section{Discussion}

\subsection{Synthesis methods}

The direct compounding process is more convenient for operation, it has a low cost and is suitable for massive production (Katsoyiannis and Zouboulis, 2002). However, some drawbacks are related to: i) the decision about the space distribution parameter of NPs on the polymer matrix, ii) the possibility of NPs to form larger agglomerates during blending, greatly decreasing the advantages of their nano-size dimensions, and iii) the polymer degradation upon melt compounding and phase separation between the nano-phase and the polymer, which is sometimes severe (Zhao et al., 2011).

In situ synthesis methods allow synthesizing nanocomposites with tailored physical properties, and with a direct and homogeneous dispersion of the NPs into the liquid monomers or precursors avoiding their agglomeration in the polymer matrix, and thus improving the interfacial interactions between both phases. However, use of solvents and/or catalysts can be necessary (Zhao et al., 2011).

In order to promote a sustainable production of PFCNs, green solvents and biologic reagents should be tested in situ synthesis methods. To the best of our knowledge, the potential effectiveness of coated adsorbents modified with biologic reagents has been discussed in Zhou et al. (2009). The use of biological macromolecules for wastewater remediation process is the goal of present research mostly driven by growing concerns about the depletion of petroleum oil reserves and environmental problems. So, in view of technological significance of PFNCs, the use of bio-polymers should be further investigated supporting better efficiency and multiple reuses, enhancing their applicability at large scale. Another aspect is related to the cross linking techniques which commonly uses glutaraldehyde (GA) or epichlorohydrin (EPI) as cross linkers. The drawbacks of both GA and EPA are the high levels of toxicity (i.e. immunogenicity and carcinogenicity) to human beings and animals. Thus, it is necessary to find environmentally friendly crosslinkers and green cross-linking techniques for PFNCs production (Zhao et al., 2015b).

\subsection{Process efficiency}

Batch studies have shown (see Table 3 ) that polymeric cation exchangers functionalized with HFO NPs PS-(HFO) represent the most common option for arsenic removal due to the high affinity of HFO for these metal ions (Etzel et al., 1997; De Marco et al., 2003; Cumbal et al., 2005; Sylvester et al., 2007; Möller et al., 2008). However, by using ACP-N $\left(\mathrm{CH}_{3}\right)_{2}$-(HFO), removal of approximately $90 \%$ of both $\mathrm{AsO}_{3}^{3-}$ and $\mathrm{AsO}_{4}^{3-}$ was obtained in only $10 \mathrm{~min}$ (Vatutsina et al., 2007). Zouboulis and Katsoyiannis (2002) noted that the removal of arsenic was greatly affected by the $\mathrm{Fe}\left(\mathrm{NO}_{3}\right)_{3}$ concentration used for the creation and doping of the iron oxide alginate beads. The amounts of doped iron oxides were 2.8 and $1.4 \mathrm{mg} \mathrm{g}^{-1}$ of Fe of wet alginate bead, respectively. The breakthrough point was reached after the treatment of around 80 and 55 bed volumes after the first and second runs, respectively.

For the removal of $\mathrm{Pb}^{2+}, \mathrm{Hg}^{2+}$ and $\mathrm{Cd}^{2+}$ the use of PA-(HFO) showed a very high adsorption potential, as shown in Table 3. PEI NCs were also found highly efficient for $\mathrm{Cr}^{6+}, \mathrm{Cu}^{2+}, \mathrm{Zn}^{2+}, \mathrm{Cd}^{2+}$, and $\mathrm{Pb}^{2+}$ removals. The use of $\mathrm{PEI}-\left(\mathrm{Fe}_{3} \mathrm{O}_{4}\right)+\mathrm{SiO}_{2}$ also produced high removal efficiencies the order being: $\mathrm{Cr}^{6+}>\mathrm{Cu}^{2+}>\mathrm{Zn}^{2+}>\mathrm{Cd}^{2+}$ with a starting concentration of $100 \mathrm{mg} \mathrm{L}^{-1}$ (Pang et al., 2011a, 2011b).

As shown in Table 4, Ch- $\left(\gamma-\mathrm{Fe}_{2} \mathrm{O}_{3}\right)$ are also highly efficient (99\%) for $\mathrm{Cu}_{2}^{+}$removal at $\mathrm{pH}>2$. The adsorption rate equilibrium was achieved after $1 \mathrm{~min}$ due to the absence of internal diffusion resistance.

\subsection{Metals dynamic speciation}

Metal complexation is often strongly $\mathrm{pH}$ dependent and a function of metal-binding affinity, ligand concentration, and ionic strength (Domingos Rute, 2015). Therefore, when the PNFCs are added to an environmental compartment, either a wastewater treatment facility or a river, where metals are present, these colloidal materials will absorb them through covalent, electrostatic, or hydrophobic interactions. If these colloidal materials are not well stabilized, they in turn can undergo several processes that are under dynamic control such as conformational changes of the organic colloids or the electrical surface field on the inorganic colloids, which implies that there will be a kinetic dependence on the metal complexation. These transformations result in a wider 
A

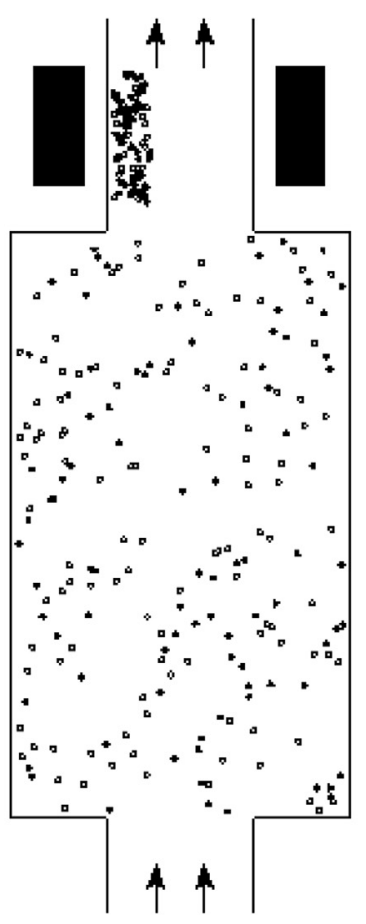

B

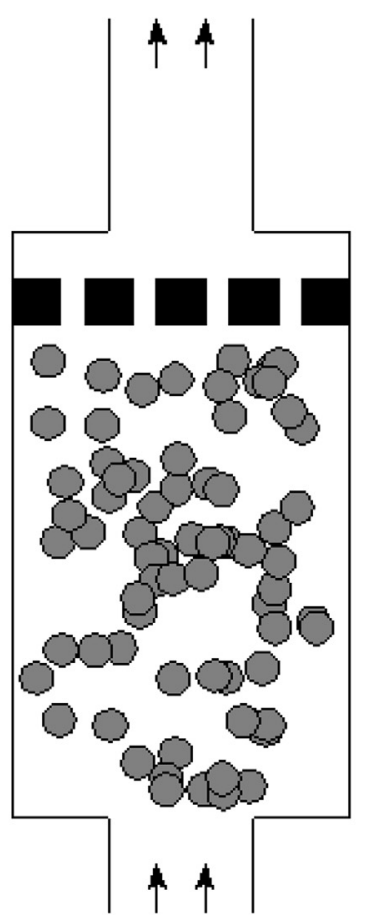

C

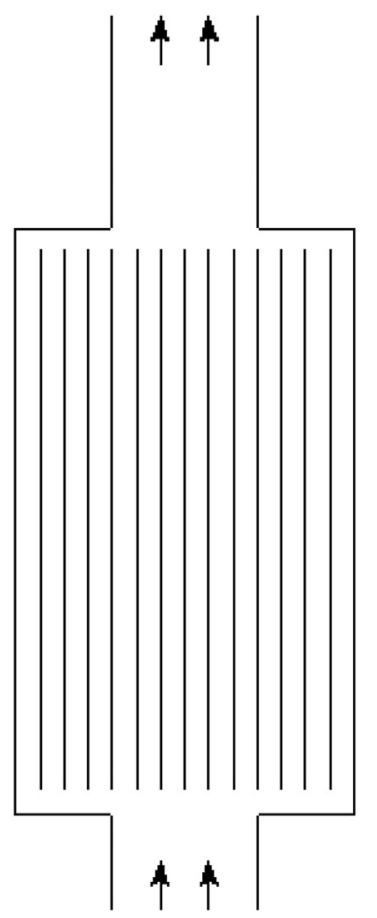

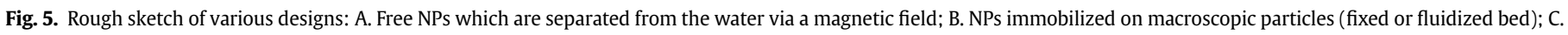
NPs immobilized on membranes.

distribution of complexation affinities for metals and metalloids, and, thus in a broader distribution of their complex dissociation kinetics. In this case, the formed complexes can have different liabilities (Herman, 2001): i) labile complexes - the kinetic flux is much larger than the diffusive one so that the free metal ion will be in equilibrium with its complex forms all along the diffusion layer, thus all metals present will contribute to the overall flux; and ii) non-labile complexes - the kinetic and diffusive fluxes are of the same order of magnitude, thus both the free metal ion and a small part of the bound metal will contribute to the overall flux. Evidently, this is of critical importance for the evaluation of the removal efficiencies if the equilibrium is not attained. When no steady state is achieved it is necessary to consider the distributions of both thermodynamic and kinetic properties on the rigorous flux computations. Moreover, it is of crucial importance considering the kinetic features of metal complexation when evaluating the toxicity through the organisms. Currently, bioavailability and toxicity models are based only on the contribution of the free species, however, due to the dynamics of these systems, consideration of the labile complex for the internalization flux could be of great importance.

\subsection{Toxicity evaluation}

Despite the growing interest in the development of PFNCs, safety for human health and the environment have not been properly addressed yet. The strict combination of polymers and NPs (Ging et al., 2014) does not ease this investigation. NPs could pose some intrinsic potential risks. For example, the biocompatibility investigations of graphene and graphene oxide have been unsatisfactory with some papers demonstrating severe dose-dependent toxicity (Hu et al., 2011; Wang et al., 2011), while others indicated that graphene NPs might improve cell growth (Lee et al., 2011; Ruiz et al., 2011). Furthermore, not only the environmental toxicity, but also the fate of NPs remains poorly understood, even for the most toxic NPs like Ag. As for toxicity effects, the fate of NPs shows NPspecific partitioning behaviour. Kaegi et al. (2013) evidenced little discharge for Ag NPs into surface waters from urban wastewater cycle, whereas Ferry et al. (2009) demonstrated how Au nano-rods could partition after an exposure period of 12 days in an aquatic mesocosm being detectable in biofilm, the water column, clams and other biota. Preferably, the use of PFNCs should reduce the release and potential toxic effects of NPs while the adsorption of the target contaminant(s) by the nanocomposites should be comparable (or higher) than that obtained from the free NPs (Önnby et al., 2014).

Currently, most data are referred mainly to PFNCs constituents and in just few cases to PFNC as a whole. Tests on whole materials and after weathering experiments (e.g., UV radiation, humidity, and chemical and biological factors) are needed considering both

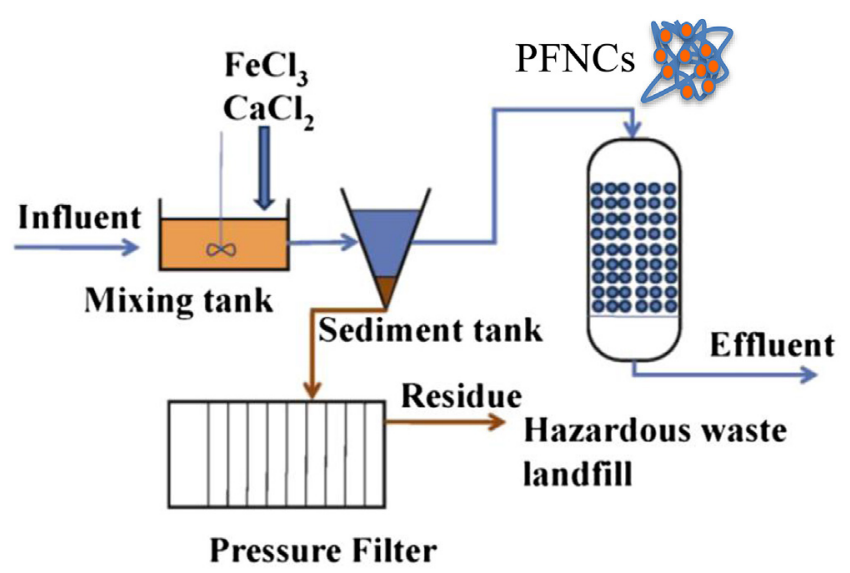

Fig. 6. Flow scheme of combined process including PFNCs (modified from Jiang et al., 2014). 
in vitro and in vivo (eco)toxicology (Posgai et al., 2011; Ging et al., 2014). Current research on the environmental stability of PFNCs focused mostly on short-term stability, while the investigation of the long-term stability is missing. Ging et al. (2014) investigated plain multi-walled carbon nanotubes (MWCNTs) and aminoMWCNTs epoxy nanocomposites (after UV weathering for $1560 \mathrm{~h}$ ) on Drosophila melanogaster embryos (survivorship and developmental rate) showing no significant increase in toxicity, probably because carbon nanotubes (CNTs) collected in abraded samples were still encapsulated in the matrix, thus limiting the exposure. Paul et al. (2015) produced silver/polymer nanocomposites functionalized by amino groups after reacting with end acidic groups from PLA and its co-polymer with PLGA. Silver/ polymer nanocomposites are used in biomedical materials and sensors, showing a low-toxicity for humans, but they inhibit the growth of a wide range of microorganisms (Chaloupka et al., 2010). PLA (Jamshidian et al., 2010) and PLGA (Makadia and Siegel, 2011) are well known as non-toxic biodegradable materials (Danhier et al., 2012). PFNCs like silver/PLA and silver/PLGA nanocomposites showed strong bactericidal properties (Escherichia coli) with almost no harmful effects to humans (Paul et al., 2015). Other PFNCs were mainly investigated for biomedical applications (for orthopaedic and dental applications) like injectable nanocomposites made of biodegradable poly(-propylene fumarate) (Shi et al., 2008) proving the absence of cytotoxicity (fibroblast cell line in vitro test).

Papers developing PFNC materials for specific water and wastewater applications did not investigate any potential (eco) toxicity effects (Katsoyiannis and Zouboulis, 2002; Chang et al., 2005, 2006; Guo and Chen, 2005; Say et al., 2006; Banerjee et al., 2007; Lim et al., 2009; Wang and Wang, 2009; Zhou et al., 2009; Tran et al., 2010; Badruddoza et al., 2011; Bée et al., 2011; Shirsath et al., 2011; Zhu et al., 2011; Badruddoza et al., 2013a,b; Musico et al., 2013). An exception was done by Önnby et al. (2014), where they investigated nanocomposites of aluminium oxide nanoparticles (Al NPs) incorporated in a PA cryogel matrix for $\mathrm{AsO}_{4}^{3-}$ removal efficiency in the perspective of creating a water filter, also demonstrating the potential toxicity of the filtrate by using human epithelial cells (Caco-2). No cell death in relation to the presence of NP was evident, but cell viability was slightly affected probably due to the levels of a residual monomer. Authors suggested further investigations stressing the PFNC system performance using higher flow speeds and composite volumes, under more aggressive $\mathrm{pH}$ conditions, and with higher ionic strength (Önnby et al., 2014).

Despite the use of PFNCs mainly as adsorbent for metals removal from water and wastewater, several issues related to their safety are still open: i) in general few data on PFNC as a whole, and very limited data for the specific water-related application is available; ii) existing stressing and weathering experiments are occasional and short-term based; and iii) scarce toxicity data are available only for cell lines and/or microorganisms still on a short time exposure, while no whole multicellular eukaryotic biological models have been considered.

\subsection{Design considerations}

Most studies concerning metal removal via PFNCs are related to laboratory-scale set-ups. This raises questions about the possibilities of deploying this technique into in situ situations. Lab-scale configurations studies evidence three main configurations, as summarized in Fig. 5.

- NPs are mixed with contaminated water, being the main problem of this approach the separation of NPs from the water.
However, if magnetic NPs are used, this can be achieved via magnetic fields to overcome the main limitation of this approach (Manju et al., 2002).

- NPs are immobilized on membrane sheets or fibres and the contaminated water passes over them making the adsorption process possible. The advantage of this design is that the NPs can be recovered, but a suitable system (i.e. sufficient capacity) might require a large surface area for efficient contaminants adsorption (Vatutsina et al., 2007). Membrane fouling is a current problem requiring to regular cleaning procedure or membrane replacement.

- NPs can be immobilized onto larger particles that are easily separated from water at or near the outlet of the treatment installation. This leads to a fixed bed or fluidized bed system, where the water flows through the pores among the particles (Katsoyiannis and Zouboulis, 2002). Fouling could reduce the effectiveness of the adsorption process, but the replacement of larger particles can be continuous.

Crucial parameters for the design are i) the total surface area available for adsorption processes determining the capacity, and ii) the achievable throughput causing the system footprint. To better elucidate the scale effect we can consider a case study where $\mathrm{Cd}$ contaminates water. Table 3 indicates an adsorption capacity of $21 \mathrm{mg}$ Cd per g of PA-(HFO) (Manju et al., 2002), where the S-PFNCs are in suspension, so that the entire surface is available for adsorption. The total surface area per unit of volume $\left(\mathrm{m}^{2} \mathrm{~L}^{-1}\right)$ is provided by Eq. (8).

$A=4 \pi R^{2} N$

where, $R$ is the radius of the S-PFNCs (considering S-PFNCs as roughly spherical), and $N$ is the number of NPs per unit of volume. This is related to the mass concentration $C$ :

$N=C /\left(\rho 4 \pi / 3 R^{3}\right)$

where, $\rho$ is the density and the denominator is the mass per NP. Combining Eq. (8) and Eq. (9) leads to:

$A=3 C / \rho R$

According to Eq. (8) and using a density of $4000 \mathrm{~kg} / \mathrm{m}^{3}$ and a radius of $50 \mathrm{~nm}$, removal of $1 \mathrm{~g} / \mathrm{m}^{3}$ of these NPs corresponds to $5 \mathrm{~m}^{2}$ surface area per $\mathrm{m}^{3}$ of suspension.

Since this concerns free-floating NPs, the full surface area is available. If the NPs are embedded in a polymer membrane, then roughly half of the surface will be available. Furthermore the NPs will be spread over the membrane and they may or may not be close together. Assuming that the S-PFNCs are indeed as close together as possible, then an estimate of the membrane area can be obtained, which will in fact be a lower limit. The adsorption of $21 \mathrm{mg} C d$ requires $1 \mathrm{~g}$ of HFO. From the above calculation the surface area of $1 \mathrm{~g}$ NPs is $5 \mathrm{~m}^{2}$. Therefore at least $5 \mathrm{~m}^{2}$ of membrane are required to adsorb that amount of $\mathrm{Cd}$ and probably more, since the NPs will be spread over the membrane rather than being very close together. This gives an idea of the dimensions of a device intended to adsorb metals from water via such membranes.

\subsection{Applications to real case wastewater}

The application of PFNCs to real wastewaters has been rarely reported in literature, and only few studies evaluated the treatment of industrial and municipal effluents. Laboratory scale results showed that phosphorus from real effluent discharged from a 
municipal WWTP can be effectively removed by HFO-201 (Hua et al., 2013b) from $0.92 \mathrm{mg} \mathrm{L}^{-1}$ to $<0.5 \mathrm{mg} \mathrm{L}^{-1}$ at a flow rate of $50 \mathrm{BV} \mathrm{h}^{-1}$ and treatable volume of 3500-4000 BV run ${ }^{-1}$. Recently, a combined process including polymer-based nanocomposite as selective adsorbent, as shown in Fig. 6, has been validated for arsenic removal from tungsten-smelting wastewater (Jiang et al., 2014). Experiments were carried out with two commercially available nanocomposites HZO-201 and HFO-201. Zr(IV)-loaded nanoadsorbent (HZO-201) exhibited higher capacity of arsenate and better performance under different $\mathrm{pH}$ values than HFO-201. The concentration of arsenic in co-precipitation effluent could be effectively decreased from $0.96 \mathrm{mg} \mathrm{L}^{-1}$ to $<0.5 \mathrm{mg} \mathrm{L}^{-1}$ by HZO-201 column within 220 BV. Fixed bed column test of $\mathrm{Tl}(\mathrm{I})$-contained industrial effluent and natural water showed that D001-(HMO) allowed to achieve a conspicuous removal of arsenic from $1.3 \mathrm{mg} \mathrm{L}^{-1}$ to a value $<0.14 \mathrm{mg} \mathrm{L}^{-1}$ (maximum concentration level for industrial effluent regulated by USEPA) and from 1 to $4 \mu \mathrm{g} \mathrm{L}^{-1}$ to a value $<0.1 \mu \mathrm{g} \mathrm{L}^{-1}$ (drinking water standard regulated by China Health Ministry), respectively (Pan et al., 2014b).

\subsection{Cost evaluation}

The cost of the materials is one of the key factors to evaluate the sustainability of PFNCs as adsorbents. The cost of producing PA(HFO) is 7 US\$ per $100 \mathrm{~g}$ which is approximately three times lower than the cost of some commercial resins such as Amberlite IRA-64, Amberlite IRP-88, Amberlite CG-50 and Duolite ES-468 (21-45 US\$ per $100 \mathrm{~g}$ of resin) (Manju et al., 2002).

The cost of modification agents should also be estimated. For instance, $\alpha$-KA is a harmless and environmental-friendly biologic reagent, while chemical modification reagents are general toxic to humans and animals, and also expensive. The cost of the $\alpha-\mathrm{KA}-\mathrm{Ch}-$ $\left(\gamma-\mathrm{Fe}_{2} \mathrm{O}_{3}\right)$ is mainly related to the $\alpha$-KA price, which is about 380 US\$ per kg depending on the preparation procedure. However, the costs of the chitosan flakes cross-linked with glutaraldehyde and chitosan-coated polyvinyl chloride beads can reach up to 15700 and 3254 US\$ per $\mathrm{kg}$, respectively. The removal efficiency of $\alpha$-KA$\mathrm{Ch}-\left(\gamma-\mathrm{Fe}_{2} \mathrm{O}_{3}\right)$ reach $50 \%$ after $2 \mathrm{~min}$, and its adsorption equilibrium can be attained after $60 \mathrm{~min}$, whereas the equilibrium time for the chitosan flakes cross-linked with glutaraldehyde can be 16 times faster. The maximum uptake of the $\alpha-\mathrm{KA}-\mathrm{Ch}-\left(\gamma-\mathrm{Fe}_{2} \mathrm{O}_{3}\right)$ is $96.15 \mathrm{mg} \mathrm{g}^{-1}$, while that of the chitosan flakes cross-linked with glutaraldehyde or chitosan-coated polyvinyl chloride beads is 85.5 or $87.9 \mathrm{mg} \mathrm{g}^{-1}$, respectively. Therefore, the $\alpha-\mathrm{KA}-\mathrm{Ch}-\left(\gamma-\mathrm{Fe}_{2} \mathrm{O}_{3}\right)$ can be considered as a viable economical alternative for the commercially available adsorbents for the removal of metals from aqueous solutions (Zhou et al., 2009).

\section{Conclusions}

In the last decade, several studies have been devoted to the application of PFNCs for metals and metalloids removal from water and wastewater. Despite the promises of these adsorbents, several issues related to their use still remain to be addressed:

- Safety for human health and the environment has not been fully assessed - further research is expected in the near future investigating the long term exposure and effects considering various biological targets;

- Greening the PFNCs production is expected in order to minimize the use of solvents and make their use more environmentally friendly;

- Removal efficiency and cost optimization per unit volume treated waiting for an economy of scale;
- Support the life cycle impact analysis according to the reuse, recovery and regeneration approaches and zero-waste perspective.

\section{Acknowledgements}

The authors thank COST - European Cooperation in Science and Technology - and the COST Action ES1205 members for the kind support, exchange of ideas and discussions.

\section{Nomenclature}

$\alpha$-KA $\quad \alpha$-ketoglutaric acid

ACP-N $\left(\mathrm{CH}_{3}\right)_{2}-(\mathrm{HFO})$ Acrylic polymer $+\mathrm{N}\left(\mathrm{CH}_{3}\right)_{2}$ supported Hydrated Iron (III) Oxide

BV bed volume

$\mathrm{CA}-\left(\gamma-\mathrm{Fe}_{2} \mathrm{O}_{3}\right)$ Calcium alginate coated iron oxide

$(C-\beta-C D)$ Carboxymethyl- $\beta$-cyclodextrin

$\mathrm{C}-\beta-\mathrm{CD}-\left(\mathrm{Fe}_{3} \mathrm{O}_{4}\right)$ Carboxymethyl- $\beta$-cyclodextrin modified $\left(\mathrm{Fe}_{3} \mathrm{O}_{4}\right)$

$\mathrm{CA}-\left(\mathrm{Fe}_{3} \mathrm{O}_{4}\right)$ Calcium alginate encapsulated $\left(\mathrm{Fe}_{3} \mathrm{O}_{4}\right)$

CA-(HFO) Calcium alginate coated hydrous iron oxide

CDs Cyclodextrins

$\mathrm{Ce}-\left(\mathrm{Fe}_{3} \mathrm{O}_{4}\right)\left(\mathrm{Fe}_{3} \mathrm{O}_{4}\right) /$ bacterial cellulose

$\mathrm{Ce}$-(HFO) Cellulose loaded with hydrous iron oxide

Ch- $\left(\gamma-\mathrm{Fe}_{2} \mathrm{O}_{3}\right)$ Chitosan coated iron oxide

$\mathrm{Ch}-\left(\mathrm{Cu}^{0}\right)$ Chitosan supported copper

$\mathrm{Ch}-\left(\mathrm{Fe}_{2} \mathrm{O}_{3}\right)$ Chitosan supported iron oxide

CNTs Carbon Nanotubes

CPDB-(HFO) Polystirene + Divinilbenzene copolymer coated by Hydrated Iron (III) Oxide

D001-(HFO) Hydrated Fe(III) oxide (HFO) Nanoparticles within a cation-exchange resin D-001

D001-(HMO) Hydrous manganese oxide (HMO) Nanoparticles within a cation-exchange resin D-001

D001-Zr(IV) Hydrated Zr(IV) oxide Nanoparticles within a cationexchange resin D-001

DETA- $\left(\mathrm{Fe}_{3} \mathrm{O}_{4}\right)$ Diethylenetriamine supported $\mathrm{Fe}_{3} \mathrm{O}_{4}$ magnetic

DTPA diethylenetriaminepentaacetic acid

EDA- $\left(\mathrm{Fe}_{3} \mathrm{O}_{4}\right)$ Ethylenediamine supported $\mathrm{Fe}_{3} \mathrm{O}_{4}$ magnetic

EDTA ethylenediaminetetraacetic acid

EDTA- $\beta$-cyclodextrin EDTA-cross-linked $\beta$-cyclodextrin

FT-IR Fourier Transform Infra-Red

$\mathrm{GA}-\left(\mathrm{Fe}_{3} \mathrm{O}_{4}\right)$ Gum arabic supported $\left(\mathrm{Fe}_{3} \mathrm{O}_{4}\right)$

HFO Hydrated Iron (III) Oxide

HFO-201 Polymer based hydrated ferric oxide nanocomposite

HMO Hydrous manganese oxide

HZO Zr(VI) loaded nano adsorbent

HSAB theory Hard-Soft Acid-Base theory

HZO-201 Polymer based zirconium nanocomposite

$\mathrm{MP}-\left(\mathrm{Fe}_{3} \mathrm{O}_{4}\right)$ Mercapto-functionalized core-shell nano-magnetic $\mathrm{Fe}_{3} \mathrm{O}_{4}$ polymers

MWCNTs Multi Walled Carbon Nanotubes

mPAA- $\left(\mathrm{Fe}_{3} \mathrm{O}_{4}\right)$ Magnetic polyacrylic acid sodium salt supported $\mathrm{Fe}_{3} \mathrm{O}_{4}$ magnetic

MP-0 Mercapto-functionalized polymer adsorbents without a $\mathrm{Fe}_{3} \mathrm{O}_{4}$ core

M-PAM- $\left(\mathrm{Fe}_{3} \mathrm{O}_{4}\right)$ Magnetic hydroxamic acid modified polyacrylamide $/ \mathrm{Fe}_{3} \mathrm{O}_{4}$ adsorbent

MSP sodium dihydrogen phosphate

$\mathrm{nZrO}_{2} \quad$ Nano Zirconium Oxide

nZrP Nano Zirconium Phosphate

nZVI Nano Zero Valent Iron

NS Polystirene anion exchanger

PA-(HFO)Polyacrylamide grafted Hydrated Iron (III) Oxide

PA Polyacrylamide 
PA-(HFO)Polyacrylamide-grafted hydrous iron(III) oxide

$\mathrm{PCl}-(\mathrm{HFO})$ Polystirene chloromethylated supported Hydrated Iron (III) Oxide

$\mathrm{PEI}-\left(\mathrm{Fe}_{3} \mathrm{O}_{4}\right)+\mathrm{SiO}_{2}$ Polyethylenimine supported $\mathrm{Fe}_{3} \mathrm{O}_{4}$ magnetic

PEI- $\left(\mathrm{Fe}_{3} \mathrm{O}_{4}\right)$ Polyethylenimine supported $\mathrm{Fe}_{3} \mathrm{O}_{4}$ magnetic

PEI-C Polyethylenimine supported nanocarbon

PEI-NC Polyethylenimine nanocomposite

PLA polyactide

PLCy- $\left(\gamma-\mathrm{Fe}_{2} \mathrm{O}_{3}\right)$ Poly-L-cysteine immobilized onto the surface of iron oxide

PLGA polyglycolide

PnV-G Poly (n-vinylcarbazole) blended with graphene oxide nanoparticles

PP polypropylene

PS-(HFO) Polystirene sulfone supported Hydrated Iron (III) Oxide

PS-(HMO) Polystirene sulfone supported Hydrated Iron (III) Oxide

PS-ZrP Polystirene sulfone supported Zirconium phosphate

$\mathrm{PS}-\mathrm{Zr}\left(\mathrm{HPO}_{3} \mathrm{~S}\right)_{2}$ Polystirene sulfone supported Zirconium hydrogen monothio phosphate

SEM Scanning Electron Microscopy

SPM Scanning Probe Microscopy

TEM Transmission Electron Microscopy

TEPA- $\left(\mathrm{Fe}_{3} \mathrm{O}_{4}\right)$ Tetraethylenepenthamine supported $\mathrm{Fe}_{3} \mathrm{O}_{4}$ magnetic

TETA- $\left(\mathrm{Fe}_{3} \mathrm{O}_{4}\right)$ Triethylenetetramine supported $\mathrm{Fe}_{3} \mathrm{O}_{4}$ magnetic

XRD X-Ray Diffraction

\section{References}

Badruddoza, A.Z.M., Tay, A.S.H., Tan, P.Y., Hidajat, K., Uddin, M.S., 2011. Carboxymethyl- $\beta$-cyclodextrin conjugated magnetic nanoparticles as nano-adsorbents for removal of copper ions: synthesis and adsorption studies. J. Hazard. Mater $185,1177-1186$.

Badruddoza, A.Z.M., Shawon, Z.B.Z., Tay, W.J.D., Hidajat, K., Uddin, M.S., 2013a. $\mathrm{Fe}_{3} \mathrm{O}_{4}$ /cyclodextrin polymer nanocomposites for selective heavy metals removal from industrial wastewater. Carbohydr. Polym. 91, 322-332.

Badruddoza, A.Z.M., Shawon, Z.B.Z., Tay, D.W.J., Hidajat, K., Uddin, M.S., 2013b. Endocrine disrupters and toxic metal ions removal by carboxymethyl- $\beta$-cyclodextrin polymer grafted onto magnetic nanoadsorbents. J. Chem. Eng. 27.

Banerjee, S.S., Chen, D.-H., 2007. Fast removal of copper ions by gum arabic modified magnetic nano-adsorbent. J. Hazard. Mater 147, 792-799.

Bée, A., Talbot, D., Abramson, S., Dupuis, V., 2011. Magnetic alginate beads for $\mathrm{Pb}(\mathrm{II})$ ions removal from wastewater. J. Colloid Interface Sci. 362, 486-492.

Bibak, A., 1994. Cobalt, copper, and manganese adsorption by aluminium and iron oxides and humic acid. Commun. Soil Sci. Plant Anal. 25, 3229-3239.

Blaney, L.M., Cinar, S., Sengupta, A.K., 2007. Hybrid anion exchanger for trace phosphate removal from water and wastewater. Water Res. 41, 1603-1613.

Carotenuto, M., Lofrano, G., Siciliano, A., Aliberti, F., Guida, M., 2014. TiO2 photocatalytic degradation of caffeine and ecotoxicological assessment of oxidation by-products. Glob. Nest J. 16 (3), 265-275.

Chang, Y.-C., Chen, D.-H., 2005. Preparation and adsorption properties of monodisperse chitosan-bound $\mathrm{Fe}_{3} \mathrm{O}_{4}$ magnetic nanoparticles for removal of $\mathrm{Cu}(\mathrm{II})$ ions. J. Colloid Interface Sci. 283, 446-451.

Chang, Y.C., Chen, D.H., 2006. Recovery of gold (III) ions by a chitosancoated magnetic nano-adsorbent. Gold Bull. 39, 98-102.

Chávez-Guajardo, A.E., Medina-Llamas, J.C., Maqueira, L., Andrade, C.A.S. Alves, K.G.B., Celso de Melo, P., 2015. Efficient removal of $\mathrm{Cr}$ (VI) and $\mathrm{Cu}$ (II) ions from aqueous media by use of polypyrrole/maghemite and polyaniline/ maghemite magnetic nanocomposites. Chem. Eng. J. 281, 826-836.

Cumbal, L., Sengupta, A.K., 2005. Arsenic removal using polymer-supported hydrated iron(III) oxide nanoparticles: role of Donnan membrane effect. Environ. Sci. Technol. 39, 6508-6515.

Danhier, F., Ansorena, E., Silva, J.M., Coco, R., Le Breton, A., Préat, V., 2012. PLGAbased nanoparticles: an overview of biomedical applications. J. Control. Release $161,505-522$.

Davis, A.P., Bhatnagar, V., 1995. Adsorption of cadmium and humic acid onto hematite. Chemosphere 30, 243-256.

De Marco, M.J., SenGupta, A.K., Greenleaf, J.E., 2003. Arsenic removal using a polymeric/inorganic hybrid sorbent. Water Res. 37, 164-176.

Domingos Rute, F., Gélabert, Alexandre, Carreira, Sara, Cordeiro, Ana, Sivry, Yann, Benedetti Marc, F., 2015. Metals in the aquatic environment - interactions and implications for the speciation and bioavailability: a critical overview. Aquat. Geochem. 21, 231-257. http://dx.doi.org/10.1007/s10498-014-9251-x.

Etzel, J.E., Kurek, J., 1997. Water treatment process. US patent n. 5,453,201.

Ferry, J.L., Craig, P., Hexel, C., Sisco, P., Frey, R., Pennington, P.L., et al., 2009. Transfer of gold nanoparticles from the water column to the estuarine food web. Nat. Nanotechnol. 4, 441-444.
Freundlich, H., 1906. Über die Adsorption in Lösungen (Wilhelm Engelmann).

Ghorbani, M., Eisazadeh, H., 2013. Removal of COD, color, anions and heavy metals from cotton textile wastewater by using polyaniline and polypyrrole nanocomposites coated on rice husk ash. Compos. B Eng. 45, 1-7.

Ging, J., Tejerina-Anton, R., Ramakrishnan, G., Nielsen, M., Murphy, K., Gorham, J.M., Nguyen, T., Orlov, A., 2014. Development of a conceptual framework for evaluation of nanomaterials release from nanocomposites: environmental and toxicological implications. Sci. Total Environ. 473-474, 9-19.

Grassi, M., Kaykioglu, G., Belgiorno, V., Lofrano, G., 2012. Removal of emerging contaminants from water and wastewater by adsorption process. In: Lofrano, G. (Ed.), Emerging Compounds Removal from Wastewater. Natural and Solar Based Treatments. Springer, ISBN 978-9-4007-3915-4.

Guo, X., Chen, F., 2005. Removal of arsenic by bead cellulose loaded with iron oxyhydroxide from groundwater. Environ. Sci. Technol. 39, 6808-6818.

Herman, P. van Leeuwen, 2001. Revisited the conception of lability of metal complexes. Electroanalysis 13, 826-830. http://dx.doi.org/10.1002/15214109(200106)13:10|826:AID-ELAN826[3.0.CO;2-J.

Hu, W., Peng, C., Lv, M., Li, X., Zhang, Y., Chen, N., Fan, C., Huang, Q., 2011. Protein corona-mediated mitigation of cytotoxicity of graphene oxide. ACS Nano 5 , 3693-3700.

Hua, M., Jiang, Y., Wu, B., Pan, B., Zhao, X., Zhang, Q., 2013a. Fabrication of a new hydrous $\mathrm{Zr}$ (IV) oxide-based nanocomposite for enhanced Pb (II) and Cd (II) removal from waters. ACS Appl. Mater. Interfaces 5 (22), 12135-12142.

Hua, M., Xiao, L., Pan, B., Zhang, Q., 2013b. Validation of polymer-based nano-iron oxide in further phosphorus removal from bioeffluent: laboratory and scaled up study. Front. Environ. Sci. Eng. 7 (3), 435-441.

Jamshidian, M., Tehrany, E.A., Imran, M., Jacquot, M., Desobry, S., 2010. Poly-lactic acid:production, applications, nanocomposites, and release studies. Compr. Rev. Food Sci. Food Saf. 9, 552-571.

Jiang, Z., Lv, L., Zhang, W., Du, O., Pan, B., Yang, L., Zhang, O., 2011. Nitrate reduction using nanosized zero-valent iron supported by polystyrene resins: role of surface functional groups. Water Res. 45 (6), 2191-2198.

Jiang, Y., Hua, M., Wu, B., Ma, H., Pan, B., Zhang, Q., 2014. Enhanced removal of arsenic from a highly laden industrial effluent using a combined coprecipitation/nano-adsorption process. Environ. Sci. Pollut. Res. 21 (10), 6729-6735.

Jin, J., Li, R., Wang, H.L., Chen, H.N., Liang, K., Ma, J.T., 2007. Magnetic Fe nanoparticle functionalized water-soluble multi-walled carbon nanotubules towards the preparation of sorbent for aromatic compounds removal. Chem. Commun. 4 386-388.

Kaegi, R., Voegelin, A., Ort, C. Sinnet, B., Thalmann, B., Krismer, J., et al., 2013. Fate and transformation of silver nanoparticles in urban wastewater systems. Wat. Res. 47 (12), 3866-3877.

Katsoyiannis, I.A., Zouboulis, A.I., 2002. Removal of arsenic from contaminated water sources by sorption onto iron-oxide-coated polymeric materials. Water Res. 36, 5141-5155.

Khare, H.S., Burris, D.L., 2010. A quantitative method for measuring nanocomposite dispersion. Polymer 51, 719-729.

Khaydarov, R.A., Khaydarov, R.R., Gapurova, O., 2010. Water purification from metal ions using carbon nanoparticle-conjugated polymer nanocomposites. Wate Res. 44, 1927-1933.

Langmuir, I., 1918. The adsorption of gases on plane surfaces of glass, mica and platinum. J. Am. Chem. Soc. 40, 1361-1403.

Lee, W.C., Lim, C.H.Y.X., Shi, H., Tang, L.A.L., Wang, Y., Lim, C.T., Loh, K.P., 2011. ACS Nano 5, 7334-7341.

Lim, S.-F., Zheng, Y.-M., Zou, S.-W., Chen, J.P., 2009. Removal of copper by calcium alginate encapsulated magnetic sorbent. Chem. Eng. J. 152, 509-513.

Mahdavian, A.R., Mirrahimi, M.A.-S., 2010. Efficient separation of heavy metal cations by anchoring polyacrylic acid on superparamagnetic magnetite nanoparticles through surface modification. Chem. Eng. J. 159, 264-271.

Makadia, H.K., Siegel, S.J., 2011. Poly lactic-co-glycolic acid (PLGA) as biodegradable controlled drug delivery carrier. Polymers 3, 1377-1397.

Manju, G.N., Anoop Krishnan, K., Vinod, V.P., Anirudhan, T.S., 2002. An investigation into the sorption of heavy metals from wastewaters by polyacrylamide-grafted iron(III) oxide. J. Hazard. Mater. 91, 221-238.

Michler, G.H. (Ed.), 2008. Electron Microscopy of in Polymers. Springer Verlag, Heidelberg.

Möller, T., Sylvester, P., 2008. Effect of silica and pH on arsenic uptake by resin/iron oxide hybrid media. Water Res, 442, 1760-1766.

Musico, Y.L.F., Santos, C.M., Dalida, M.L.P., Rodrigues, D.F., 2013. Improved removal of lead (ii) from water using a polymer-based graphene oxide nanocomposite. J. Mat. Chem. A 1, 3789-3796.

Nah, I.W., Hwang, K.Y., Jeon, C., Choi, H.B., 2006. Removal of Pb ion from water by magnetically modified zeolite. Min. Eng. 19, 1452-1455.

Nassar, N.N., 2010. Rapid removal and recovery of $\mathrm{Pb}(\mathrm{II})$ from wastewater by magnetic nanoadsorbents. J. Hazard. Mater. 184, 538-546.

Nie, G., Pan, B., Zhang, S., Pan, B., 2013. Surface chemistry of nanosized hydrated ferric oxide encapsulated inside porous polymer: modeling and experimental studies. J. Phys. Chem. C 117 (12), 6201-6209.

Nie, G., Wang, J., Pan, B., Lv, L., 2015. Surface chemistry of polymer-supported nanohydrated ferric oxide for arsenic removal: effect of host pore structure. Sci. China Chem. 58 (4), 722-730.

Norkus, E., 2009. Metal ion complexes with native cyclodextrins. An overview. J. Incl. Phenom. Macrocycl. Chem. 65, 237-248.

Önnby, L., Svensson, C., Mbundi, L., Busquets, R., Cundy, A., Kirsebom, H., 2014. $\gamma$ - 
Al203-based nanocomposite adsorbents for arsenic (V) removal: assessing performance, toxicity and particle leakage. Sci. Total Environ. 473, 207-214.

Pan, B., Pan, B., Chen, X., Zhang, W., Zhang, X., Zhang, Q., Zhang, Q., Chen, J., 2006 Preparation and preliminary assessment of polymer-supported zirconium phosphate for selective lead removal from contaminated water. Water Res. 40, 2938-2946.

Pan, B., Su, Q., Zhang, W., Zhang, Q., Ren, H., Zhang, Q. et al., (2007). A process to prepare a hydrid sorbent by impregnating hydrous manganese dioxide (HMO) nanoparticles within polymer for enhanced removal of heavy metals. Chinese Patent No. ZL 200710134050.9.

Pan, B., Pan, B., Zhang, W., Lv, L., Zhang, Q., Zheng, S., 2009. Development of polymeric and polymer-based hybrid adsorbents for pollutants removal from waters. Chem. Eng. J. 151, 19-29.

Pan, B., Qiu, H., Pan, B., Nie, G., Xiao, L., Lv, L., Zhang, W., Zhang, Q., Zheng, S., 2010. Highly efficient removal of heavy metals by polymer-supported nanosized hydrated Fe(III) oxides: behavior and XPS study. Water Res. 44, 815-824.

Pan, S., Zhang, Y., Shen, H., Hu, M., 2012. An intensive study on the magnetic effect of mercapto-functionalized nano-magnetic $\mathrm{Fe}_{3} \mathrm{O}_{4}$ polymers and their adsorption mechanism for the removal of $\mathrm{Hg}$ (II) from aqueous solution. Chem. Eng. J. 210, 564-574.

Pan, B., Han, F., Nie, G., Wu, B., He, K., Lu, L., 2014a. New strategy to enhance phosphate removal from water by hydrous manganese oxide. Environ. Sci. Technol. 48 (9), 5101-5107.

Pan, B., Wan, S., Zhang, S., Guo, Q., Xu, Z., Lv, L., Zhang, W., 2014b. Recyclable polymer-based nano-hydrous manganese dioxide for highly efficient Tl (I) removal from water. Sci. China Chem. 57 (5), 763-771.

Pang, Y., Zeng, G., Tang, L., Zhang, Y., Liu, Y., Lei, X., Li, Z., Zhang, J., Xie, G., 2011a. PEIgrafted magnetic porous powder for highly effective adsorption of heavy metal ions. Desalination 281, 278-284.

Pang, Y., Zeng, G., Tang, L., Zhang, Y., Liu, Y., Lei, X., Li, Z., Zhang, J., Liu, Z., Xiong, Y., 2011b. Preparation and application of stability enhanced magnetic nanoparticles for rapid removal of $\mathrm{Cr}(\mathrm{VI})$. Chem. Eng. J. 175, 222-227.

Paul, A., Kaverina, E., Vasiliev, A., 2015. Synthesis of silver/polymer nanocomposites by surface coating using carbodiimide method. Colloids Surfaces Physicochem. Eng. Aspects 482, 44-49.

Posgai, R., Cipolla-McCulloch, C.B., Murphy, K.R., Hussain, S.M., Rowe, J.J. Nielsen, M.G., 2011. Differential toxicity of silver and titanium dioxide nanoparticles on Drosophila melanogaster development, reproductive effort, and viability: size, coatings and antioxidants matter. Chemosphere 85 (1), 34-42.

Qiu, H., Zhang, S., Pan, B., Zhang, W., Lv, L., 2012. Effect of sulfate on Cu (II) sorption to polymer-supported nano-iron oxides: behavior and XPS study. J. Colloid Interface Sci. 366 (1), 37-43.

Qiu, H., Zhang, S., Pan, B., Zhang, W., Lv, L., 2013. Oxalate-promoted dissolution of hydrous ferric oxide immobilized within nanoporous polymers: effect of ionic strength and visible light irradiation. Chem. Eng. J. 232, 167-173.

Qu, X., Alvarez, P.J.J., Li, Q., 2013. Applications of nanotechnology in water and wastewater treatment. Water Res. 47, 3931-3946.

Razzaz, A., Ghorban, S., Hosayni, L., Irani, M., Aliabadi, M., 2016. Chitosan nanofibers functionalized by $\mathrm{TiO}_{2}$ nanoparticles for the removal of heavy metal ions. J. Taiwan Inst. Chem. Eng. 33, 333-343.

Ruiz, O.N., Fernando, K.A.S., Wang, B., Brown, N.A., Luo, P.G., McNamara, N.D. Vangsness, M., Sun, Y.-P., Bunker, C.E., 2011. ACS Nano 5, 8100-8107.

Sadeghi, S., Alavi Rad, F., Moghaddam, A.Z., 2014. A highly selective sorbent for removal of $\mathrm{Cr}(\mathrm{VI})$ from aqueous solutions based on $\mathrm{Fe}_{3} \mathrm{O}_{4} /$ poly(methyl methacrylate) grafted Tragacanth gum nanocomposite: optimization by experimental design. Mater. Sci. Eng. C 45, 136-145.

Sarkar, S., SenGupta, A.K., 2010. The Donnan membrane principle opportunities for sustainable engineered processes and materials. Environ. Sci. Technol. 44, 1161-1166.

Sarkar, S., Chatterjee, P.K., Cumbal, L.H., SenGupta, A.K., 2011. Hybrid ion exchanger supported nanocomposites: sorption and sensing for environmental applications. Chem. Eng. J. 166, 923-931.

Say, R., Birlik, E., Denizli, A., Ersöz, A., 2006. Removal of heavy metal ions by dithiocarbamate-anchored polymer/organosmectite composites. Appl. Clay Sci. 31, 298-305.

Shen, Haoyu, et al., 2012. A new insight on the adsorption mechanism of aminofunctionalized nano- $\mathrm{Fe}_{3} \mathrm{O}_{4}$ magnetic polymers in $\mathrm{Cu}$ (II), $\mathrm{Cr}$ (VI) co-existing water system. Chem. Eng. J. 183, 180-191.

Shi, X., Sitharaman, B., Pham, Q.P., Spicer, P.P., Hudson, J.L., Wilson, L.J., Tour, J.M.
Raphael, R.M., Mikos, A.G., 2008. In vitro cytotoxicity of single-walled carbon nanotube/biodegradable polymer nanocomposites. J. Biomed. Mater. Res. A 86A, 813-823.

Shirsath, S.R., Hage, A.P., Zhou, M., Sonawane, S.H., Ashokkumar, M., 2011. Ultrasound assisted preparation of nanoclay Bentonite-FeCo nanocomposite hybrid hydrogel: a potential responsive sorbent for removal of organic pollutant from water. Desalination 281, 429-437.

Sylvester, P., Westerhoff, P., Möller, T., Badruzzaman, M., Boyd, O., 2007. A hybrid sorbent utilizing nanoparticles of hydrous iron oxide for arsenic removal from drinking water. Environ. Eng. Sci. 24, 104-112.

Tran, H.V., Tran, L.D., Nguyen, T.N., 2010. Preparation of chitosan/magnetite composite beads and their application for removal of $\mathrm{Pb}(\mathrm{II})$ and $\mathrm{Ni}(\mathrm{II})$ from aqueous solution. Mater. Sci. Eng. C 30, 304-310.

Vatutsina, O.M., Soldatov, V.S., Sokolova, V.I., Johann, J., Bissen, M., Weissenbacher, A., 2007. A new hybrid (polymer/inorganic) fibrous sorbent for arsenic removal from drinking water. React. Funct. Polym. 67, 184-201.

Wang, J., Zhang, S., Pan, B., Zhang, W., Lv, L., 2011. Hydrous ferric oxide-resin nanocomposites of tunable structure for arsenite removal: effect of the host pore structure. J. Hazard. Mater. 198, 241-246.

Wang, J., Gerlach, J.D., Savage, N., Cobb, G.P., 2013. Necessity and approach to integrated nanomaterial legislation and governance. Sci. Total Environ. 442, 56-62.

Weber, T.W., Chakravorti, R.K., 1974. Pore and solid diffusion models for fixed-bed adsorbers. AIChE J. 20, 228-238.

White, B.R., Stackhouse, B.T., Holcombe, J.A., 2009. Magnetic - $\mathrm{Fe}_{2} \mathrm{O}_{3}$ nanoparticles coated with poly-l-cysteine for chelation of $\mathrm{As}(\mathrm{III}), \mathrm{Cu}(\mathrm{II}), \mathrm{Cd}(\mathrm{II}), \mathrm{Ni}(\mathrm{II}), \mathrm{Pb}(\mathrm{II})$ and $\mathrm{Zn}(\mathrm{II})$. J. Hazard. Mater. 161, 848-853.

Wu, S.-J., Liou, T.-H., Mi, F.-L., 2009. Synthesis of zero-valent copper-chitosan nanocomposites and their application for treatment of hexavalent chromium. Bioresour. Technol. 100, 4348-4353.

Yu, L., Zou, R., Zhang, Z., Song, G., Chen, Z., Yang, J., et al., 2011. A $\mathrm{Zn}_{2} \mathrm{GeO}_{4}^{-}$ethylenediamine hybrid nanoribbon membrane as a recyclable adsorbent for the highly efficient removal of heavy metals from contaminated water. Chem. Commun. 47, 10719-10721.

Zhang, Q., Pan, B., Pan, B., Zhang, W., Jia, K., Zhang, Q., 2008. Selective sorption of lead, cadmium and zinc ions by a polymeric cation exchanger containing nano$\mathrm{Zr}\left(\mathrm{HPO}_{3} \mathrm{~S}\right)_{2}$. Environ. Sci. Technol. 42, 4140-4145.

Zhang, Q., Pan, B., Zhang, S., Wang, J., Zhang, W., Lv, L., 2011. New insights into nanocomposite adsorbents for water treatment: a case study of polystyrenesupported zirconium phosphate nanoparticles for lead removal. J. Nanoparticle Res. 13 (10), 5355-5364.

Zhang, Q., Du, Q., Hua, M., Jiao, T., Gao, F., Pan, B., 2013. Sorption enhancement of lead ions from water by surface charged polystyrene-supported nano-zirconium oxide composites. Environ. Sci. Technol. 47, 6536-6544.

Zhao, Y.-G., Shen, H.-Y., Pan, S.-D., Hu, M.-O., Xia, O.-H., 2010. Preparation and characterization of amino-functionalized nano- $\mathrm{Fe}_{3} \mathrm{O}_{4}$ magnetic polymer adsorbents for removal of chromium(VI) ions. J. Mater. Sci. 45, 5291-5301.

Zhao, X., Lv, L., Pan, B., Zhang, W., Zhang, S., Zhang, Q., 2011. Polymer-supported nanocomposites for environmental application: a review. Chem. Eng. J. 170, $381-394$.

Zhao, F., Tang, W.Z., Zhao, D., Meng, Y., Yin, D., Sillanpää, M., 2014. Adsorption kinetics, isotherms and mechanisms of Cd (II), Pb (II), Co (II) and Ni (II) by a modified magnetic polyacrylamide microcomposite adsorbent. J. Water Process Eng. 4, 47-57.

Zhao, F., Repo, E., Yin, D., Meng, Y., Jafari, S., Sillanpää, M., 2015a. EDTA-cross-linked $\beta$-cyclodextrin: an environmentally friendly bifunctional adsorbent for simultaneous adsorption of metals and cationic dyes. Environ. Sci. Technol. 49 (17), $10570-10580$.

Zhao, F., Repo, E., Sillanpää, M., Meng, Y., Yin, D., Tang, W.Z., 2015b. Green synthesis of magnetic EDTA-and/or DTPA-cross-linked chitosan adsorbents for highly efficient removal of metals. Ind. Eng. Chem. Res. 54 (4), 1271-1281.

Zhou, Y.-T., Nie, H.-L., Branford-White, C., He, Z.-Y., Zhu, L.-M., 2009. Removal of $\mathrm{Cu} 2+$ from aqueous solution by chitosan-coated magnetic nanoparticles modified with alpha-ketoglutaric acid. J. Colloid Interface Sci. 330, 29-37.

Zhu, H., Jia, S., Wan, T., Jia, Y., Yang, H., Li, J., Yan, L., Zhong, C., 2011. Biosynthesis of spherical Fe304/bacterial cellulose nanocomposites as adsorbents for heavy metal ions. Carbohydr. Polym. 86, 1558-1564.

Zouboulis, A.I., Katsoyiannis, I.A., 2002. Arsenic removal using iron oxide loaded alginate beads. Ind. Eng. Chem. Res. 41, 6149-6155. 